\title{
Is coccolithophore distribution in the Mediterranean Sea related to seawater carbonate chemistry?
}

\author{
A. Oviedo ${ }^{1}$, P. Ziveri ${ }^{1,2,5}$, M. Álvarez ${ }^{3}$, and T. Tanhua ${ }^{4}$ \\ ${ }^{1}$ Institute of Environmental Science and Technology (ICTA), Universitat Autònoma de Barcelona (UAB), \\ 08193 Bellaterra, Spain \\ ${ }^{2}$ Earth \& Climate Cluster, Department of Earth Sciences, FALW, Vrije Universiteit Amsterdam, \\ FALW, HV1081 Amsterdam, the Netherlands \\ ${ }^{3}$ IEO - Instituto Español de Oceanografia, Apd. 130, A Coruña 15001, Spain \\ ${ }^{4}$ GEOMAR Helmholtz-Zentrum für Ozeanforschung Kiel, Marine Biogeochemistry, Düsternbrooker Weg 20, \\ 24105 Kiel, Germany \\ ${ }^{5}$ ICREA, Institució Catalana de Recerca i Estudis Avançats, Barcelona, Spain \\ Correspondence to: A. Oviedo (angelamaria.oviedo@uab.cat)
}

Received: 31 December 2013 - Published in Ocean Sci. Discuss.: 20 February 2014

Revised: 24 June 2014 - Accepted: 1 November 2014 - Published: 9 January 2015

\begin{abstract}
The Mediterranean Sea is considered a "hot spot" for climate change, being characterized by oligotrophic to ultra-oligotrophic waters and rapidly increasing seasurface temperature and changing carbonate chemistry. Coccolithophores are considered a dominant phytoplankton group in these waters. As marine calcifying organisms they are expected to respond to the ongoing changes in seawater carbonate chemistry. We provide here a description of the springtime coccolithophore distribution in the Mediterranean Sea and relate this to a broad set of in situ-measured environmental variables. Samples were taken during the R/V Meteor (M84/3) oceanographic cruise in April 2011, between 0 and $100 \mathrm{~m}$ water depth from 28 stations. Total diatom and silicoflagellate cell concentrations are also presented. Our results highlight the importance of seawater carbonate chemistry, especially $\left[\mathrm{CO}_{3}^{2-}\right]$ but also $\left[\mathrm{PO}_{4}^{3-}\right]$ in unraveling the distribution of heterococcolithophores, the most abundant coccolithophore life phase. Holo- and heterococcolithophores respond differently to environmental factors. For instance, changes in heterococcolithophore assemblages were best linked to the combination of $\left[\mathrm{CO}_{3}^{2-}\right]$, $\mathrm{pH}$, and salinity $(\rho=0.57)$, although salinity might be not functionally related to coccolithophore assemblage distribution. Holococcolithophores, on the other hand, showed higher abundances and species diversity in oligotrophic areas (best fit, $\rho=0.32$ for nutrients), thriving in nutrient-depleted
\end{abstract}

waters. Clustering of heterococcolithophores revealed three groups of species sharing more than $65 \%$ similarities. These clusters could be assigned to the eastern and western basins and deeper layers (below $50 \mathrm{~m}$ ), respectively. In addition, the species Gephyrocapsa oceanica, G. muellerae, and Emiliania huxleyi morphotype $\mathrm{B} / \mathrm{C}$ are spatially distributed together and trace the influx of Atlantic waters into the Mediterranean Sea. The results of the present work emphasize the importance of considering holo- and heterococcolithophores separately when analyzing changes in species assemblages and diversity. Our findings suggest that coccolithophores are a main phytoplankton group in the entire Mediterranean Sea and can dominate over siliceous phytoplankton. They have life stages that are expected to respond differently to the variability in seawater carbonate chemistry and nutrient concentrations.

\section{Introduction}

Marine phytoplankton constitutes about 1-2\% of the global biomass among primary producers (Falkowski, 1994); however, it contributes to $\sim 46 \%$ of the primary production in a global scale (Field et al., 1998). Coccolithophores represent $\sim 10 \%$ of global phytoplankton biomass (Tyrrell and Young, 2009). They play an important role in biogeochemical cy- 
cles, contributing to both the organic and inorganic carbon pumps through photosynthesis and calcification. The latter is the main process controlling PIC: POC (rain ratio). For instance, in the eastern Mediterranean Sea, they are the main contributor to the inorganic carbon pump $\left(\mathrm{CaCO}_{3}\right.$ production and flux) throughout the year (Knappertsbusch, 1993; Ziveri et al., 2000; Malinverno et al., 2003).

Most studies looking at coccolithophore assemblages and distribution take into account parameters such as nutrients, photosynthetically active radiation (PAR), temperature, salinity, and oxygen (e.g., Young, 1994; Ziveri et al., 1995; Hagino et al., 2000; Takahashi and Okada, 2000; Haidar and Thierstein, 2001; Cortés et al., 2001; Ignatiades et al., 2009). Parameters related to the seawater carbonate system have only recently been considered due to their importance for calcification and the ongoing and projected changes directly related to the rapidly increasing atmospheric $p \mathrm{CO}_{2}$. Carbonate chemistry parameters have been suggested as drivers of coccosphere morphology modification in field samples (Beaufort et al., 2008, 2011; Meier et al., 2014; Triantaphyllou et al., 2010), Emiliania huxleyi blooms (Merico et al., 2006; Tyrrell et al., 2008), and changes in coccolithophore assemblage composition (Charalampopoulou et al., 2011). Although it is not clear why coccolithophores calcify, calcification is an energy-consuming process for coccolithophores (Brand, 1994; Balch, 2004), maintained by natural selection over millions of years, that changes the carbonate chemistry of their surrounding media. It is therefore plausible that the availability of the necessary resources for carrying out calcification (i.e., $\mathrm{HCO}_{3}^{-}$and $\mathrm{CO}_{3}^{2-}$ ) should facilitate coccolithophore's growth in the ocean. In this context, it is important to understand how marine calcifying organisms could respond to the rapid accumulation of atmospheric $\mathrm{CO}_{2}$ and their interaction with the ocean's carbonate chemistry (Kroeker et al., 2013).

The Mediterranean Sea provides an ideal ground to explore the factors controlling coccolithophore distribution because of the well-known large gradient in physicochemical parameters. It has a negative fresh-water balance, with evaporation exceeding precipitation. Surface water temperature, salinity, total alkalinity (TA), and $\left[\mathrm{CO}_{3}^{2-}\right]$ increase towards the eastern basin. The Mediterranean Sea is one of the most nutrient-poor regions of the global ocean (Dugdale and Wilkerson, 1988), with a trophic status ranging from mesotrophic in the northwest to extremely oligotrophic in the east (Krom et al., 1991; Berman et al., 1984; Berland et al., 1988; Yacobi et al., 1995; Psarra et al., 2000). The spatial distribution of the phytoplankton community along an east-west transect shows that coccolithophores can dominate along the Mediterranean Sea, in the Levantine, Ionian, and Tyrrhenian basins (Ignatiades et al., 2009). Ocean acidification, warming, and changes in nutrient availability are expected to significantly alter primary production rates, as well as the overall plankton community structure. Studies on coccolithophores distribution in the Mediterranean Sea are mostly regional (Dimiza et al.,
2008; Malinverno et al., 2003), losing part of the abovementioned gradients. Additionally, carbonate chemistry parameters were not available in older studies focussed on the distribution of coccolithophores in the Mediterranean Sea. Thus comparisons between the different basins are scarce and the influence of carbonate chemistry parameters on actual coccolithophore assemblages remains therefore uncertain.

The present work investigates the regional and vertical distribution of living coccolithophores in the Mediterranean Sea with respect to in situ-measured environmental parameters and with focus on those of the carbonate chemistry. It provides a description of the late springtime coccolithophore assemblage's composition and distribution in the Mediterranean Sea, with a basin resolution that has not been assessed before, and along physical and chemical gradients.

\section{Material and methods}

\subsection{Sampling}

A detailed water sampling was conducted during the M84/3 cruise from 6 to 28 April 2011 onboard the R/V Meteor (Tanhua et al., 2013a). Here we investigate a subset of 81 samples from 28 stations collected between 0 and $100 \mathrm{~m}$ water depth. Samples were taken using a carousel of 24 Niskin bottles interfaced with the SBE911 CTD system (SeaBird) that provided the hydrographical data for in situ temperature, salinity, and dissolved oxygen of the seawater samples. Samples collected at $<1 \mathrm{~m}$ water depth were obtained by filling a $5 \mathrm{~L}$ plastic container with surface water. Between 1.5 and $4.5 \mathrm{~L}$ of water was gently filtered onto acetate cellulose membranes (Millipore, $0.45 \mu \mathrm{m}$ pore size, $47 \mathrm{~mm}$ diameter). Membrane filters were oven-dried at $40^{\circ} \mathrm{C}$ for $\sim 12 \mathrm{~h}$ and stored in sealed Petri dishes. Figure 1 shows the location of all sampled stations during the cruise trajectory. Table 1 shows the stations coordinates, dates, and sampled depths. The bottle data can be found at http://cdiac.ornl.gov/ ftp/oceans/CLIVAR/Met_84_3_Med_Sea/.

\subsection{Phytoplankton analyses}

A portion of each filter was placed on aluminum stubs and gold-coated using an EMITECH K550X sputter coater. The quantification and identification of the main phytoplankton groups and coccolithophore species were performed by JEOL-JSM 6300 and ZEISS-EVO MA10 scanning electron microscopes (SEMs). Transects of $5-15 \mathrm{~mm}$ on the filter, corresponding to an average of $2.3 \mathrm{~mL}$ of seawater, were observed at 3000x and phytoplankton groups quantified as coccolithophores, diatoms, and silicoflagellates (Dictyocha spp.). A subset of five random samples was analyzed under a light microscope for estimation of coccolithophore and diatom cell abundance at 1000x. This was done in order to check whether counts at higher magnification were biased towards smaller cells. This comparison showed that 
Table 1. Location, date, and water depth from which the samples were collected.

\begin{tabular}{|c|c|c|c|c|c|c|c|c|c|}
\hline \multirow[t]{2}{*}{ Station } & \multirow[t]{2}{*}{ Month/day/year } & \multirow{2}{*}{$\begin{array}{r}\text { Longitude } \\
\left({ }^{\circ} \mathrm{E}\right)\end{array}$} & \multirow{2}{*}{$\begin{array}{l}\text { Latitude } \\
\left({ }^{\circ} \mathrm{N}\right)\end{array}$} & \multirow{2}{*}{$\begin{array}{r}\text { Bot. depth } \\
(\mathrm{m})\end{array}$} & \multicolumn{5}{|c|}{ Sampled depth (m) } \\
\hline & & & & & 100 & 50 & 25 & 5 & 0 \\
\hline 287 & $4 / 6 / 2011$ & 25.60 & 37.67 & 829 & $\mathrm{X}^{*}$ & & $X$ & $X$ & \\
\hline 288 & $4 / 7 / 2011$ & 26.22 & 35.65 & 2293 & & & $\mathrm{X}$ & $\mathrm{X}$ & \\
\hline 291 & $4 / 8 / 2011$ & 33.00 & 34.07 & 2474 & $\mathrm{X}$ & $\mathrm{X}$ & $X$ & $X$ & \\
\hline 292 & $4 / 9 / 2011$ & 35.17 & 33.99 & 1681 & & & & $X$ & \\
\hline 293 & $4 / 9 / 2011$ & 34.42 & 34.00 & 2034 & & & & $X$ & \\
\hline 294 & $4 / 10 / 2011$ & 31.00 & 33.70 & 2437 & $\mathrm{X}$ & $\mathrm{X}$ & $\mathrm{X}$ & $X$ & $\mathrm{X}$ \\
\hline 296 & $4 / 11 / 2011$ & 28.77 & 33.58 & 2934 & & & $X$ & & \\
\hline 297 & $4 / 11 / 2011$ & 26.02 & 34.40 & 4210 & $X$ & & $X$ & $X$ & \\
\hline 298 & $4 / 12 / 2011$ & 24.33 & 34.50 & 3287 & & & $X$ & $X$ & \\
\hline 299 & $4 / 12 / 2011$ & 22.50 & 35.00 & 3117 & & & & $X$ & \\
\hline 302 & $4 / 13 / 2011$ & 20.35 & 35.07 & 2968 & $X$ & $\mathrm{X}$ & $\mathrm{X}$ & $X$ & $\mathrm{X}$ \\
\hline 305 & $4 / 14 / 2011$ & 17.25 & 35.60 & 4440 & & & $\mathrm{X}$ & $X$ & \\
\hline 306 & $4 / 15 / 2011$ & 19.00 & 36.50 & 3445 & & $X$ & $X$ & $X$ & \\
\hline 307 & $4 / 15 / 2011$ & 19.30 & 37.90 & 3305 & & & & $X$ & $\mathrm{X}$ \\
\hline 308 & $4 / 15 / 2011$ & 19.00 & 38.50 & 3462 & $X$ & $X$ & & $X$ & $X$ \\
\hline 309 & $4 / 16 / 2011$ & 18.80 & 39.50 & 805 & $X$ & $\mathrm{X}$ & $X$ & & \\
\hline 313 & $4 / 16 / 2011$ & 18.00 & 41.25 & 1105 & & & $X$ & $X$ & \\
\hline 316 & $4 / 19 / 2011$ & 11.50 & 38.60 & 1665 & & & $X$ & $X$ & \\
\hline 319 & $4 / 20 / 2011$ & 11.30 & 40.30 & 2880 & & & & $X$ & $\mathrm{X}$ \\
\hline 320 & $4 / 20 / 2011$ & 10.61 & 38.75 & 2490 & $X$ & & & $X$ & \\
\hline 321 & $4 / 20 / 2011$ & 9.40 & 38.25 & 1565 & $\mathrm{X}$ & $\mathrm{X}$ & $\mathrm{X}$ & $X$ & \\
\hline 324 & $4 / 21 / 2011$ & 5.60 & 38.65 & 2845 & $X$ & $\mathrm{X}$ & $\mathrm{X}$ & $X$ & $\mathrm{X}$ \\
\hline 329 & $4 / 23 / 2011$ & 2.00 & 37.90 & 2730 & $X$ & $X$ & $X$ & $X$ & $\mathrm{X}$ \\
\hline 331 & $4 / 23 / 2011$ & 0.00 & 37.05 & 2704 & $X$ & $X$ & $X$ & $X$ & $\mathrm{X}$ \\
\hline 332 & $4 / 24 / 2011$ & -1.40 & 36.50 & 2340 & & & $X$ & $X$ & \\
\hline 334 & $4 / 24 / 2011$ & -4.40 & 36.10 & 1228 & $X$ & $\mathrm{X}$ & $X$ & $X$ & \\
\hline 337 & $4 / 25 / 2011$ & -5.36 & 36.00 & 935 & $X$ & $\mathrm{X}$ & $X$ & $X$ & $\mathrm{X}$ \\
\hline 338 & $4 / 25 / 2011$ & -5.75 & 35.95 & 337 & & & & $X$ & \\
\hline
\end{tabular}
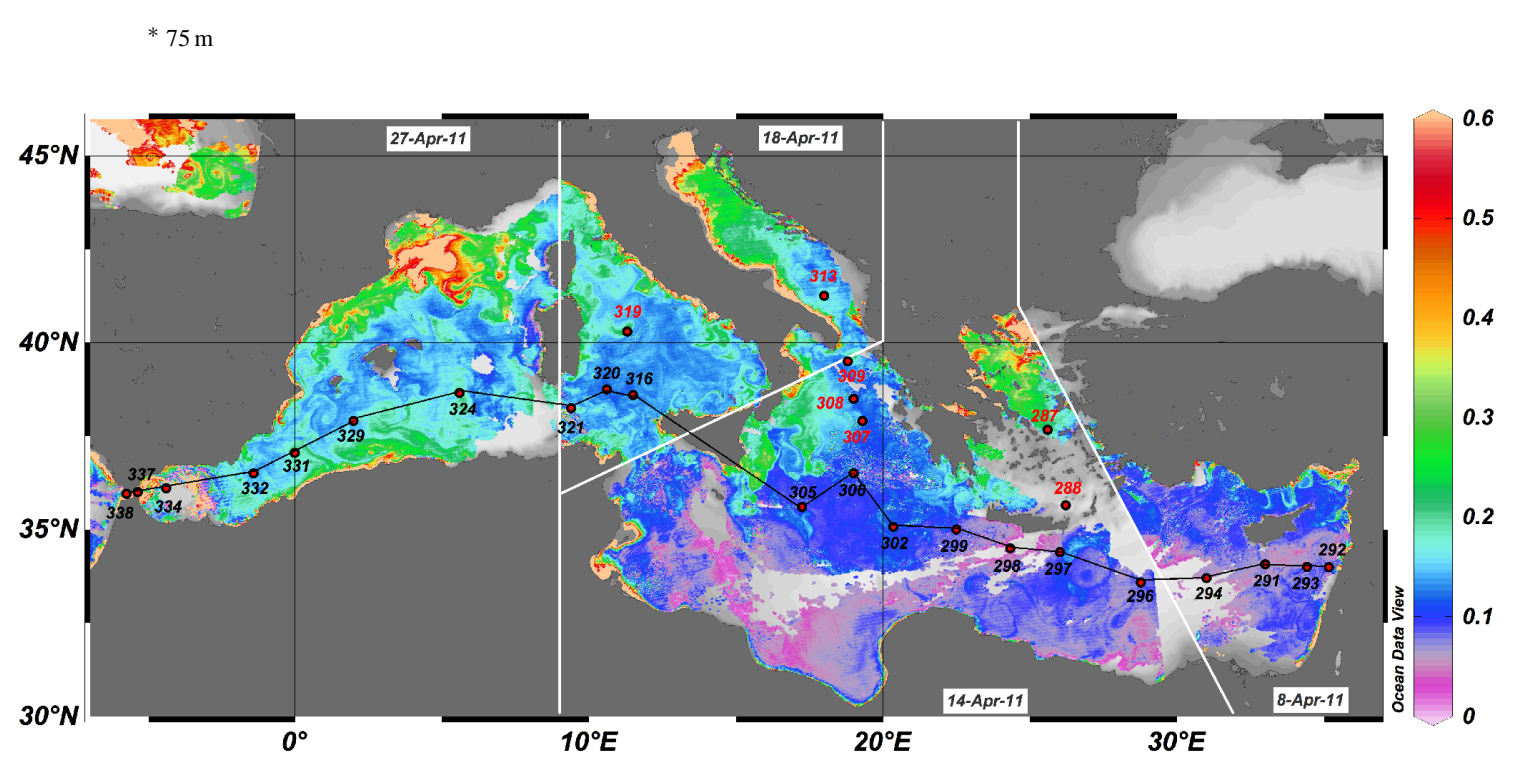

Figure 1. Sampling stations presented in this study collected during the M84-3 research cruise. A composite image is superimposed showing the surface chlorophyll concentration $\left(\mathrm{mg} \mathrm{m}^{-3}\right)$ at an approximate date of the sampling period in the different basins. The transect shown in the following figures includes the stations labeled in black. 
relative abundances of diatoms were similar in the two methods. They comprised between 1.7 and $3.3 \%(\mathrm{SD}=0.85)$ of cells counted via optical microscopy and between 0.8 and $4.1 \%(\mathrm{SD}=1.6)$ of cells counted via SEM. Coccolithophore species were identified and their absolute and relative abundances counted. In samples with very few coccospheres a larger filter portion was observed in order to quantify a minimum of 100 cells (a maximum number of 420 cells were counted). Lower $\left(C_{\mathrm{L}}\right)$ and upper $\left(C_{\mathrm{U}}\right)$ confidence intervals at $95 \%$ significance were estimated following Bollmann et al. (2002). For a 100-cell count these were $C_{\mathrm{L}}=82$ and $C_{\mathrm{U}}=102$, and for a 420-cell count: $C_{\mathrm{L}}=382$ and $C_{\mathrm{U}}=422$. Cell densities (number of cells per liter of seawater) were calculated. Emiliania huxleyi was sub-classified into morphotypes according to Young et al. (2003). For each sample the Shannon-Wiener diversity index (H') was calculated for heterococcolithophores and holococcolithophores. These two groups were treated separately because they represent two different stages of a coccolithophore's life cycle, and taxonomy between the two does not always account for it.

\subsection{Environmental parameters}

A detailed protocol of all measured environmental variables can be found in Tanhua et al. (2013a). In situ salinity, temperature, and oxygen data were measured with a CTD (described in Sect. 2.1). Overall data accuracies were $0.002{ }^{\circ} \mathrm{C}$ for temperature and 0.003 for salinity. Macronutrients (phosphate and nitrate and silicate concentrations) were measured onboard with a QuAAtro autoanalyzer from SEAL Analytical. The following protocols from SEAL Analytical were followed: nitrate $\left(\mathrm{NO}_{3}\right)$ (method no. Q-068-05 rev. 4), phosphate $\left(\mathrm{PO}_{4}^{3-}\right)$ (method no. Q-031-04 rev. 2), and silicium (Si) (method no. Q-066-05 rev. 3). The nutrient analytical error was determined on 5-7 sample replicates taken at selected stations. The error for nitrate is $0.08 \mu \mathrm{mol} \mathrm{kg}-1$, for phosphate $0.007 \mu \mathrm{mol} \mathrm{kg}{ }^{-1}$, and for silicate $0.10 \mu \mathrm{mol} \mathrm{kg}{ }^{-1}$.

The carbonate system was characterized by measuring dissolved inorganic carbon (DIC), $\mathrm{pH}$, and total alkalinity (TA). DIC content was measured coulometrically using a SOMMA (single-operator multi-metabolic analyzer) system. The precision of the analysis is $\pm 0.6 \mu \mathrm{mol} \mathrm{kg}{ }^{-1}$ and the accuracy is $2.5 \mu \mathrm{mol} \mathrm{kg}{ }^{-1}$. The $\mathrm{pH}$ was measured by means of doublewavelength spectrophotometry, and it is reported at $25^{\circ} \mathrm{C}$ on the total scale. The reproducibility of the $\mathrm{pH}$ measurements was 0.0012 . TA was analyzed following a double-end-point potentiometric technique. The precision of the TA measurements was $0.1 \mu \mathrm{mol} \mathrm{kg}-1$. More details about the DIC, TA, and $\mathrm{pH}$ measurements and quality control are presented in Álvarez et al. (2014). In situ conditions for other $\mathrm{CO}_{2}$-related variables were calculated from in situ $\mathrm{pH}$ and TA for the first $100 \mathrm{~m}$ water column. Calculations were performed using the program CO2Sys (Lewis and Wallace, 1998). Equilibrium constants of Mehrbach et al. (1973) refitted by Dickson and Millero (1987) were chosen (Álvarez et al., 2014).
A characterization of the upper $100 \mathrm{~m}$ environmental parameters is shown in Fig. 2; the profiles for the complete water column at a higher spatial horizontal resolution and a full description of the physicochemical setting are presented in Tanhua et al. (2013b) and Álvarez et al. (2014) in this Ocean Science special issue.

\subsection{Statistical analyses}

The E-PRIMER v.5 package was used for the following analyses:

- (1) The BIOENV routine, which computes a rank correlation between the elements of similarity matrices for environmental parameters and biological data, was run to detect the combined changes in environmental parameters and species distribution among stations. The routine examines all possible combinations of environmental variables and gives the "best fit" (higher RhoSpearman rank correlation) of environmental variables explaining changes in biological communities. This test was performed for all heterococcolithophore and holococcolithophore species contributing $>2 \%$ to the total assemblage of each group. Before running the routine, we checked for mutual correlation among environmental variables and selected a subset of them for this routine. These were salinity, temperature, oxygen, $\mathrm{pH}$, partial pressure of carbon dioxide $\left(p \mathrm{CO}_{2}\right)$, and the concentrations of bicarbonate ion $\left(\mathrm{HCO}_{3}^{-}\right)$, carbonate ion $\left(\mathrm{CO}_{3}^{-2}\right), \mathrm{NO}_{3}+\mathrm{NO}_{2}$, and $\mathrm{PO}_{4}^{3-}$.

- (2) Hierarchical cluster analyses by group average. These were performed for heterococcolithophore and holococcolithophore species. Emiliania huxleyi morphotype A was removed of the data set used to run the cluster analyses. This was done to emphasize our results on overall community composition and not on E. huxleyi, which largely dominated the assemblages in our samples. When clusters among species were detected, pair-wise Spearman correlations were performed using the software SPSSv18 to assess the environmental parameters influencing changes in each species' abundance.

For the analyses performed using E-PRIMER software, the biological data were transformed in logarithmic scale $\log (1+x)$ to avoid overemphasizing the dominant species. Environmental data were standardized (-mean-STD) to bring data into a comparable scale. Similarity matrices were created for biological and environmental data. For the biological data the Bray-Curtis similarity coefficient was used to examine similarity between each sample's pair. Euclidean distances were used to create the environmental data matrix. Pair-wise Spearman correlations were performed on the basis of non-transformed, non-standardized data. 

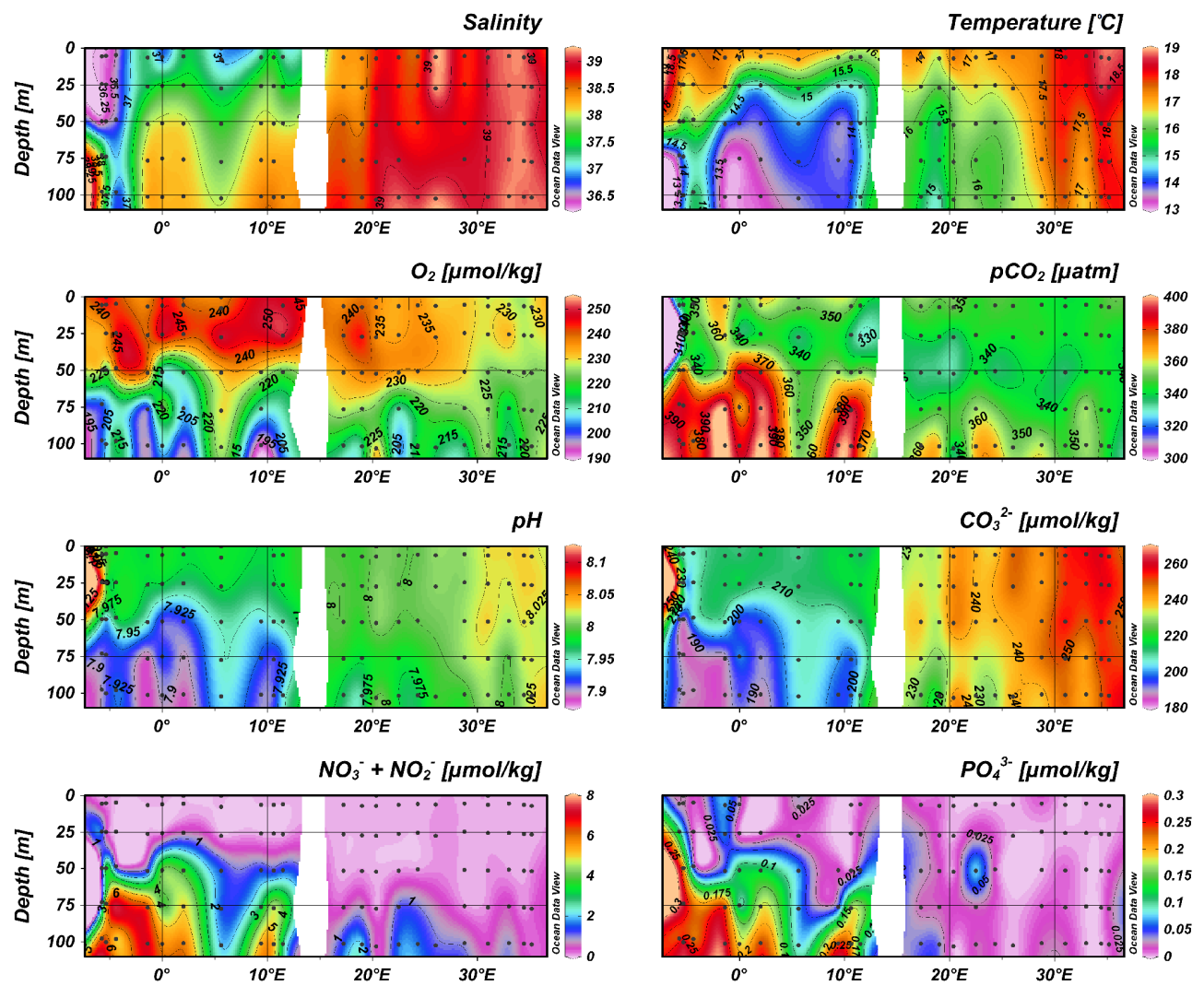

Figure 2. Environmental parameters at sampling stations for surface waters during the M84-3 cruise. The west-east transect along the Mediterranean Sea does not take into account the stations in the Aegean, Adriatic, the northernmost Ionian, or northern Tyrrhenian regions. It includes the stations labeled in black (west-east transect) in Fig. 1.

\section{Regional settings}

The Mediterranean Sea can be divided into two basins with a general counterclockwise circulation: the western and eastern basins. The Strait of Sicily prevents deep-water exchange between the two. The upper layer (from the surface down to $150-200 \mathrm{~m}$, according to the basin and the season) is occupied by the Atlantic Water (AW) (Ribera d'Alcalà et al., 2003). In the western Mediterranean, AW flows along the eastern part of the Alboran Sea in an anticyclonic fashion, and moves to the western Alboran in a more variable pattern (Robinson et al., 2001). Further east, the AW is transported along the Algerian slope until the Sardinia Channel. Part of the flow then proceeds to the eastern basin along the Tunisian slope, while the other part reaches northern Sicily and circulates along Italy. In the north, the Liguro-ProvencoCatalan Current, is form by AW surrounding Corsica. AW closes its western gyre southeast of Spain, where it encounters the newly entered AW (see Robinson et al., 2001, for more details). In the eastern basin, a jet of Atlantic Water enters through the Strait of Sicily, meanders through the interior of the Ionian Sea and continues to flow through the central Levantine all the way to the shores of Israel (Robinson et al., 2001). Convection occurs when the water approaches the
Rhodos gyre. Another part of the AW flow moves to the Ionian and a part of it goes further into the Adriatic Sea. Deepwater formation also occurs in the Adriatic gyre (Pinardi and Masetti, 2000).

During the M84/3 cruise, the surface layer in the western basin was filled by the inflow of relatively low-salinity AW through the Strait of Gibraltar. The salinity minimum, in the surface layer of the strait, shows the entrance of this water into the Mediterranean. Once it reaches the Sicily Channel (close to stations 304/305), the salinity minimum was found at $\sim 100 \mathrm{~m}$ depth. (Hainbucher et al., 2014). In terms of carbonate chemistry, AW from the surface western Mediterranean was characterized by TA below $2560 \mu \mathrm{mol} \mathrm{Kg}{ }^{-1}$, DIC near $2250 \mu \mathrm{mol} \mathrm{Kg}{ }^{-1}$, and $\mathrm{pH}$ of 8 (Àlvarez et al., 2014). In the surface layer, AW with salinity lower than 38 was detected in all the Tyrrhenian stations except 319 in the center of the basin, where salinity was higher. There, Álvarez et al. (2014) suggest that the upper $\sim 50$ dbar was occupied by probably AW affected by evaporation or mixed with the salty intermediate water entering through the Strait of Sicily. During the M84/3 cruise, modified AW and Levantine Surface Water (LSW) dominated the eastern Mediterranean, down to approximately $100 \mathrm{~m}$ water depth. The LSW, formed 

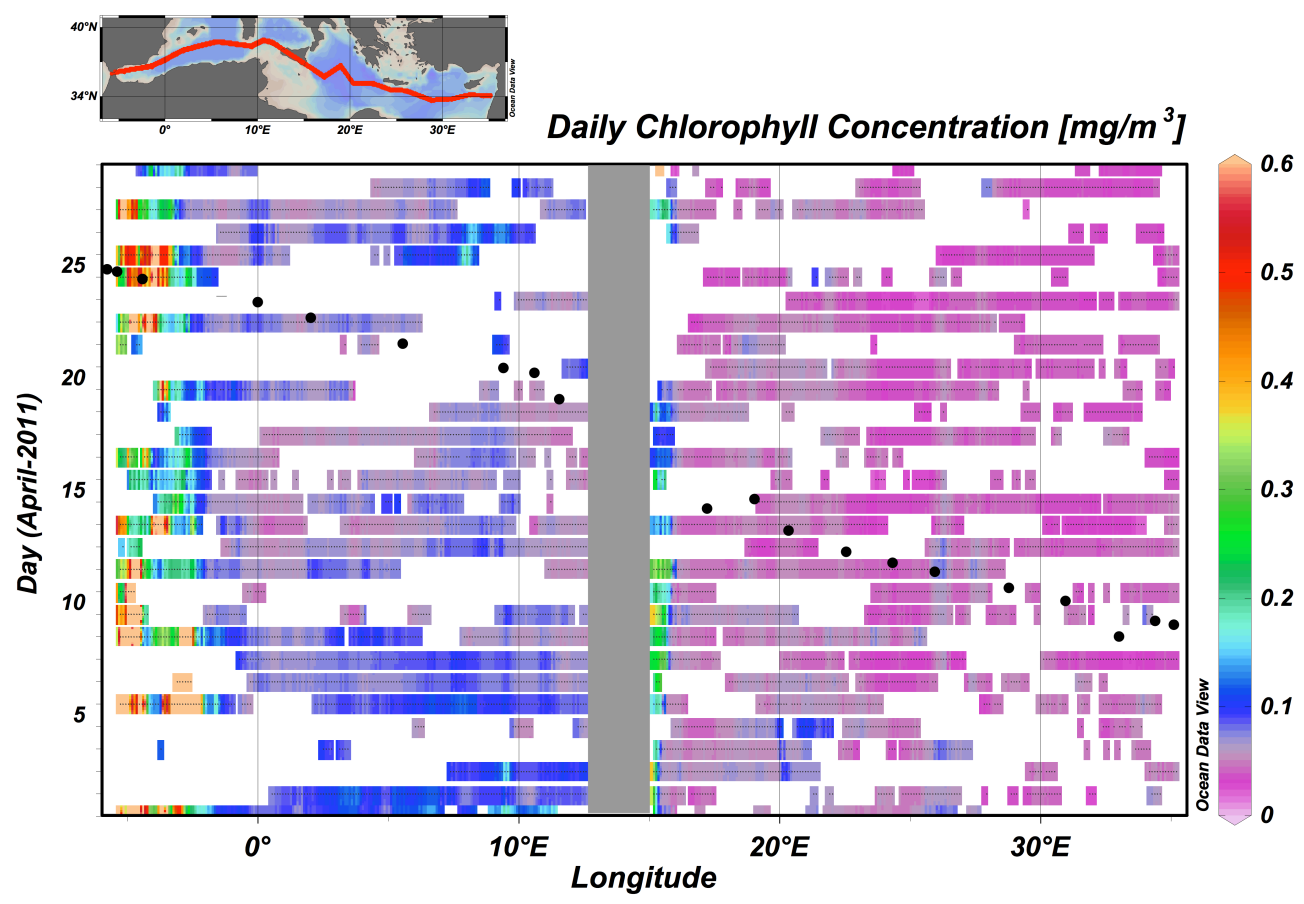

Figure 3. Daily mean chlorophyll $a$ concentration from satellite data (Volpe et al., 2012) along the transect of the M84/3 cruise, plotted for the month of April 2011. In this figure, gaps correspond to cloud-covered observations and the temporal-spatial location of the samplings during our study is indicated by black dots. The transect is representative of $18 \mathrm{~km}$ in latitude (two pixels at $9 \mathrm{~km}$ resolution).

by intensive heating and evaporation, has the largest salinity and temperature of the entire Mediterranean $\left(>17^{\circ} \mathrm{C}\right.$, > 38.9), and has TA values around $2610 \mu \mathrm{mol} \mathrm{Kg}^{-1}$, DIC around $2270 \mu \mathrm{mol} \mathrm{Kg}{ }^{-1}$, and $\mathrm{pH} 25 \mathrm{~T}$ around 8.03 (Álvarez et al., 2014). Levantine Intermediate Water (LIW) was detected at $\sim 50-100 \mathrm{~m}$ in the Levantine Sea, along its path from the northeastern Levantine Sea, and in the Rhodes cyclonic gyre (Hainbucher et al., 2014, and references therein). Close to the M84/3 trajectory, wind-induced upwelling and downwelling zones are found in different seasons (see Bakun and Agostini, 2001): for instance, (1) downwelling along the southern coastal boundary during winter, reversing to coastal upwelling off Libya in spring and off Algeria in summer and fall; (2) strong upwelling in the eastern Aegean Sea throughout the year, becoming remarkably intense in the summer and fall; and (3) strong summer and fall upwelling in the eastern Ionian Sea.

Figure 3 shows daily variations in cloud coverage during the month of April (from satellite observations). It provides an overview of the meteorological situation and possible short-term variability that may mask any relationship with long-term average oceanographic gradients. Approximately half of the satellite observations were cloud covered, with a minimum in cloud coverage ( $\sim 40 \%$ of observations) at about $25^{\circ} \mathrm{E}$ (south of Crete). This minimum corresponds to the only segment of the transect directly influenced by northern wind regimes. Such approximation can be compared with the meteorological reports during the M84/3 (data not shown), which shows that $\sim 58 \%$ of the sampling days were cloudy (at the time of recording), with the majority of sunny days from southern Crete towards the Adriatic. Therefore, the sampled days were representative, in terms of cloud coverage, of the conditions during April 2011.

\section{Results}

\subsection{Main phytoplankton community}

Overall, phytoplankton cell density was highest in the western Mediterranean Sea, in the Strait of Gibraltar and in the Alboran Sea. For coccolithophores, the pattern was not one of gradual increase towards the west but rather of localized spots of higher cell densities close to Gibraltar and a continuous presence, at lower cell densities, in the rest of the Mediterranean. The satellite-derived chlorophyll $a$ concentration during April 2011 (Fig. 3) shows a similar pattern. Coccolithophores were the most abundant phytoplankton group during the sampling, relative to siliceous phytoplankton. They were present in great numbers in all the main Mediterranean basins and accounted for 68 to $99 \%$ of counted phytoplankton. Diatoms, although present in all studied basins, displayed low concentrations in the eastern Mediterranean, increasing towards the west. They were on average $6 \%$ (maximum $25 \%$ ) of total phytoplankton. Silicoflagellates (Dictyocha spp.) accounted on average for 

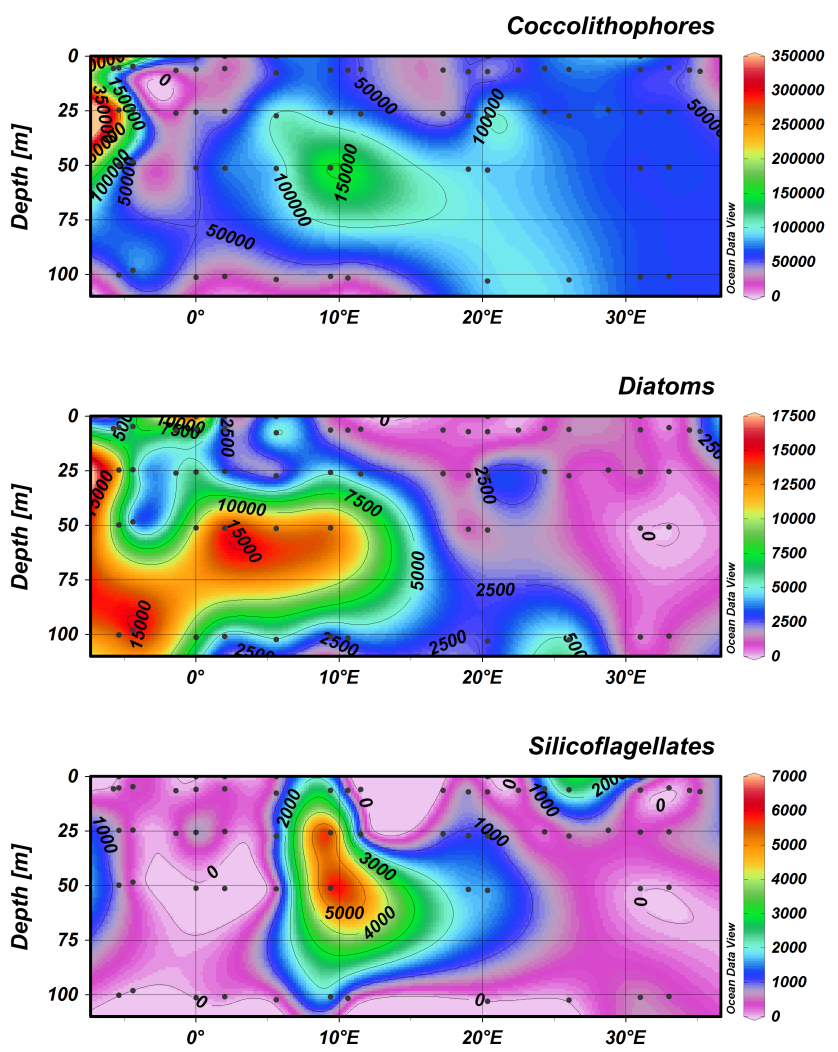

Figure 4. Distribution of coccolithophores (upper panel), diatoms (middle panel), and silicoflagellates (lower panel) in a west-east transect along the Mediterranean Sea (the transect includes the stations labeled in black in Fig. 1).

$1 \%$ of phytoplankton (maximum $9 \%$ ). Figure 4 shows the distribution of these different phytoplankton groups in the Mediterranean transect. A species present mostly at low cell densities was the xanthophyte Meringosphaera mediterranea.

\subsection{Environmental factors controlling coccolithophore community distribution}

A total of 70 coccolithophore species in heterococcolithophore life stage and 45 in the holococcolithophore stage were recorded (see Appendix A). The majority of the quantified cells were in the heterococcolithophore phase. The species Emiliania huxleyi largely dominated the coccolithophore counts in all stations except for station 319 (at the center of the Tyrrhenian Basin), where Corisphaera gracilis and Rabdosphaera clavigera were the dominant species.

The results from the Spearman's rank-correlation-based routine (BIOENV) suggest that holococcolithophores were preferentially distributed in low-nutrient, high-pH seawaters. $(\rho=0.328$, Table 2$)$. They were almost absent at $100 \mathrm{~m}$. Heterococcolithophore distribution was best linked to a combi- nation of $\left[\mathrm{CO}_{3}^{2-}\right], \mathrm{pH}$, and salinity with $\rho=0.566$ as well as to $\left[\mathrm{PO}_{4}^{3-}\right]$ (Table 3).

\subsection{Species assemblages}

When clustering all the species within the heterococcolithophore life stage, three groups or assemblages were identified that shared more than $65 \%$ similarities. Figure 5 presents the results of further clustering of the species with high similarities. The distribution of these species along the east-west transect (stations with black labels in Fig. 1) that includes the stations in the Levantine, Ionian (excluding 307-309), Tyrrhenian (excluding 319), Algerian, Alboran, and Gibraltar regions shows that the three groups are distinctively distributed in the Mediterranean Sea (Figs. 5, 6, and 7). The first group comprises species that were more abundant in the eastern stations: $U$. tenuis, D. tubifera, $P$. vandelii, S. pulchra, $R$. clavigera, and $S$. protrudens ( $R$. xyphos was very close to this cluster, with similarity $>50 \%$ ). P. vandelii, however, was patchily distributed all along the transect. The second group includes E. huxleyi Type B/C and the Gephyrocapsa species: G. ericsonii, G. muellerae, and G. oceanica. These species were almost exclusive of the western basin. A third group was formed by Florisphaera profunda and Gladiolithus flabellatus, being closely related to A. robusta and $H$. carteri (the last two with similarities between 40 and $60 \%$ ). The species in the latter group were almost restricted to depths below $50 \mathrm{~m}$, with higher abundances at $100 \mathrm{~m}$, and were patchily present from the Algerian to the Levantine basins. Clustering analysis for the holococcolith phase did not reveal any pattern in the species composition among the different samples.

Single Spearman correlations for the species that were clustered together reveal that their distribution can be better explained by seawater carbonate chemistry parameters; for instance, species that were mostly abundant at eastern stations thrived in waters with higher $\left[\mathrm{CO}_{3}^{2-}\right]$ and $\mathrm{pH}$ and in the surface. Among these species, $U$. tenuis, $R$. clavigera, S. pulchra, and $S$. protrudens were negatively correlated to phosphate concentrations and only $D$. tubifera showed a high positive correlation with temperature. Finally, F. profunda and $G$. flabellatus were correlated to $\left[\mathrm{NO}_{3}+\mathrm{NO}_{2}\right]$ and negatively with temperature. Table 4 shows these results.

\subsection{Species diversity (H')}

Hetero- and holococcolithophore species diversity index $\left(\mathrm{H}^{\prime}\right)$ changed slightly in the W-E transect. Although correlations between $\mathrm{H}^{\prime}$ and the longitude of the sample sites $\left({ }^{\circ} \mathrm{E}\right)$ in the first $50 \mathrm{~m}$ water column were rather weak, the trend was opposite for the two life stages. For instance, heterococcolithophore diversity tended to decrease towards the east ( $\rho=-0.419, p=0.000$ ), while holococcolithophore species diversity tended to increase W-E $(\rho=0.310 ; p=0.005)$ (Fig. 9). H' index at $100 \mathrm{~m}$ was often zero for both 
Table 2. Rho values $(\rho)$ for the best Spearman's rank correlations for all possible combinations between the environmental parameters explaining patterns in holococcolithophore assemblages. Only $\rho>0.2$ are shown. Description as in Table 1 . On the left, the number of variables taken into account; on the right, description of the variables and the highest $\rho$ values for the rank correlations at a given number of variables. In the first row, the $\rho$ value for each variable is shown in decreasing order of contribution to explain changes in the biological data. Only $\rho>0.2$ are shown.

\begin{tabular}{cllllllll}
\hline $\begin{array}{c}\text { Number of } \\
\text { variables }\end{array}$ & \multicolumn{7}{c}{ Variables $(\rho)$} \\
\hline 1 & $\mathrm{NO}_{3}^{-}+\mathrm{NO}_{2}^{-}$ & $(0.275) ;$ & $\mathrm{PO}_{4}^{3-}$ & $(0.236) ;$ & $\mathrm{pH}$ & $(0.214) ;$ & $p \mathrm{CO}_{2}$ & $(0.204) ;$ \\
2 & $\mathrm{NO}_{3}^{-}+\mathrm{NO}_{2}^{-}$ & $\mathrm{pH}$ & $(0.327)$ & & & & & \\
3 & $\mathrm{NO}_{3}^{-}+\mathrm{NO}_{2}^{-}$ & $\mathrm{PO}_{4}^{3-}$, & $\mathrm{pH}$ & $(0.328)$ & & & & \\
4 & $\mathrm{NO}_{3}^{-}+\mathrm{NO}_{2}^{-}$ & $\mathrm{pH}^{3-} \mathrm{O}_{2}$, & $\mathrm{Salinity}$ & $(0.311)$ & & & \\
5 & $\mathrm{NO}_{3}^{-}+\mathrm{NO}_{2}^{-}$ & $\mathrm{PO}_{4}^{3-}$, & $\mathrm{pH}, \mathrm{O}_{2}$, & salinity & $(0.311)$ & & \\
6 & $\mathrm{NO}_{3}^{-}+\mathrm{NO}_{2}^{-}$ & $\mathrm{PO}_{4}^{3-}$, & $\mathrm{pH}, p \mathrm{CO}_{2}, \mathrm{O}_{2}$, salinity & & $(0.299)$ & \\
7 & $\mathrm{NO}_{3}^{-}+\mathrm{NO}_{2}^{-}$ & $\mathrm{PO}_{4}^{3-}$, & $\mathrm{pH}, p \mathrm{CO}_{2}, \mathrm{O}_{2}$, salinity, & Temperature & & $(0.283)$ \\
8 & $\mathrm{All}$ & $(0.275)$ & & & & & \\
\hline
\end{tabular}

Table 3. Rho values $(\rho)$ for the best Spearman's rank correlations for all possible combinations between the environmental parameters explaining patterns in heterococcolithophore assemblages. Description as in Table 2.

\begin{tabular}{|c|c|c|c|c|c|c|c|c|c|c|c|c|}
\hline \multirow{2}{*}{$\begin{array}{c}\begin{array}{c}\text { Number of } \\
\text { variables }\end{array} \\
1\end{array}$} & \multicolumn{12}{|c|}{ Variables $(\rho)$} \\
\hline & $\mathrm{CO}_{3}^{2-}$ & $(0.551) ; \quad \mathrm{pH}(0.498)$ & $p \mathrm{CO}_{2}$ & (0.397); & $\mathrm{PO}_{4}^{3-}$ & (0.358); & $\mathrm{NO}_{3}^{-}+\mathrm{NO}_{2}^{-}$ & (0.328); & salinity & $(0.310)$ & $\mathrm{O}_{2}$ & (0.226); \\
\hline 2 & $\mathrm{CO}_{3}^{2-}$ & salinity $\quad(0.563)$ & & & & & & & & & & \\
\hline 3 & $\mathrm{CO}_{3}^{2-}$ & $\mathrm{pH}$, salinity & $(0.566)$ & & & & & & & & & \\
\hline 4 & $\mathrm{CO}_{3}^{2-}$ & $\mathrm{pH}, \mathrm{PO}_{4}^{3-}$, salinity & & $(0.565)$ & & & & & & & & \\
\hline 5 & $\mathrm{CO}_{3}^{2-}$ & $\mathrm{pH}, p \mathrm{CO}_{2}, \mathrm{PO}_{4}^{3-}$, salini & & & $(0.539)$ & & & & & & & \\
\hline 6 & $\mathrm{CO}_{3}^{2-}$ & $\mathrm{pH}, p \mathrm{CO}_{2}, \mathrm{PO}_{4}^{3-}$, salini & $y$, temper & ture & & $(0.517)$ & & & & & & \\
\hline 7 & $\mathrm{CO}_{3}^{\hat{2}-}$ & $\mathrm{pH}, p \mathrm{CO}_{2}, \mathrm{PO}_{4}^{3-}$, salini & $\mathrm{y}, \mathrm{O}_{2}$, ten & perature & & & $(0.507)$ & & & & & \\
\hline 8 & All & $(0.491)$ & & & & & & & & & & \\
\hline
\end{tabular}

groups, being on average 0.3 for holococcolithophores, which are mostly present at surface, and 1.3 for heterococcolithophores.

\section{Discussion}

\subsection{Main phytoplankton community}

Although picoplankton can seasonally dominate phytoplankton assemblages in the Mediterranean Sea (Decembrini et al., 2009; Yacobi et al., 1995), previous studies have often suggested that coccolithophores are one of the most abundant phytoplankton groups in this sea, in both the eastern (e.g., Gotsis-Skretas et al., 1999; Malinverno et al., 2003; Ignatiades et al., 1995, 2009; Rabitti et al., 1994; Ziveri et al., 2000) and western basins (e.g Barlow et al., 1997; Barcena et al., 2004, Ignatiades et al., 2009). Our findings suggest that coccolithophores are a main phytoplankton group in the entire Mediterranean Sea that dominated over siliceous phytoplankton for the period under study (Fig. 4). Silicoflagellates were almost absent at $100 \mathrm{~m}$ and more abundant at surface waters of the Tyrrhenian Sea, with cell densities up to
$6.7 \times 10^{3}$ cells $\mathrm{L}^{-1}$. Diatoms were preferentially distributed in the western Mediterranean Sea, in waters with lower $\left[\mathrm{CO}_{3}^{2-}\right] \mathrm{pH}$ and higher $\mathrm{PO}_{4}^{3-}$ at a maximum cell density of $1.6 \times 10^{4}$ cells $\mathrm{L}^{-1}$ (Fig. 4). Diatom cell densities in the Mediterranean ranged from a few individuals in the Ionian Sea surface to $\sim 3.5 \times 10^{4}$ in the Tyrrhenian Sea (June 1999; Ignatiades et al., 2009), from $0.8 \times 10^{3}$ to $2 \times 10^{4}$ (July 2005, Decembrini et al., 2009), from $0.2 \times 10^{3}$ to $5 \times 10^{3}$ (September-October 2004, Lasternas; et al., 2011), and from $0.7 \times 10^{3}$ to $2.6 \times 10^{3}$ cells $^{-1}$ (December 2005; Decembrini et al., 2009) in the Tyrrhenian Sea. Without taking into account interannual variability, this suggests a pattern of enhanced diatom abundances in the first part of the year and a decrease after July.

In the last decades, many attempts to explain the temporal and spatial phytoplankton distribution based on few key environmental factors have been made. Some of the most discussed are the hypothesis of Sverdrup (1953), stating that changes in phytoplankton abundances are light- and nutrientcontrolled features, and the so-called Margalef's mandala (Margalef, 1978), which proposes that phytoplankton succession depends on nutrient concentration and turbulence. Regarding the possible role of light in the relative success of 
Table 4. Three highest Spearman's correlation $(\rho)$ results for (1) the dominant species Emiliania huxleyi, (2) each of the species belonging to the observed clusters with the environmental parameters, (3) the holo- and hetero-life phases of the same species, and (4) hetero- and holococcolithophore abundances and diversity $\left(\mathrm{H}^{\prime}\right)$ and abundances of siliceous phytoplankton groups. Preferential depth and distribution along the west-east transect is described. Number of samples taken into account for the analysis is also shown $(N)$. Significance level was 0.05 .

\begin{tabular}{|c|c|c|c|c|c|}
\hline \multirow{2}{*}{$\begin{array}{l}\text { Species/group } \\
\text { E. huxleyi Type A }\end{array}$} & \multicolumn{3}{|c|}{ Variable $(r, N)$} & \multirow{2}{*}{$\begin{array}{l}\text { Pref. depth } \\
0-100 \mathrm{~m}\end{array}$} & \multirow{2}{*}{$\begin{array}{l}\text { Pref. distribution } \\
\text { W-E }\end{array}$} \\
\hline & $\mathrm{pH}(0.468 ; 73)$ & $\mathrm{CO}_{2}(-0.448 ; 73)$ & $\mathrm{CO}_{3}^{2-}(0.444 ; 73)$, & & \\
\hline E. huxleyi Type B/C & Salinity $(-0.691 ; 81)$, & $\mathrm{CO}_{3}^{2-}-(-0.685 ; 73)$, & $\mathrm{pH}(-0.616 ; 73)$ & $0-100 \mathrm{~m}$ & $\mathrm{~W}$ \\
\hline G. ericsonii & Salinity $(-0.805 ; 81)$, & $\mathrm{CO}_{3}^{2-}(-0690 ; 73)$ & $\mathrm{pH}(-0.576 ; 73)$ & Above $50 \mathrm{~m}$ & $\mathrm{~W}$ \\
\hline G. oceanica & $\mathrm{CO}_{3}^{2-}(-0.833 ; 73)$ & Salinity $(-0.803 ; 81)$ & $\mathrm{pH}(-0.731 ; 73)$ & $0-100 \mathrm{~m}$ & W \\
\hline G. muellerae & $\mathrm{CO}_{3}^{2-}(-0.835 ; 73)$ & Salinity $(-0.830 ; 81)$ & $\mathrm{pH}(-0.707 ; 73)$ & $0-100 \mathrm{~m}$ & $\mathrm{~W}$ \\
\hline U. tenuis & $\mathrm{CO}_{3}^{2-}(0.626 ; 73)$ & $\mathrm{pH}(0.605 ; 73)$ & $\mathrm{PO}_{4}^{3-}(-0.551 ; 74)$ & Above $50 \mathrm{~m}$ & $\mathrm{E}$ \\
\hline R. clavigera & $\mathrm{CO}_{3}^{2-}(0.727 ; 73)$ & $\mathrm{pH}(0.701 ; 73)$ & $\mathrm{PO}_{4}^{\frac{4}{3-}-}(-0.546 ; 74)$ & Above $50 \mathrm{~m}$ & $\mathrm{E}$ \\
\hline D. tubifera & $\mathrm{pH}(0.600 ; 73)$ & Temperature $(0.597 ; 81)$, & $\mathrm{CO}_{3}^{2-}(0.541 ; 73)$ & Above $50 \mathrm{~m}$ & E \\
\hline S. pulchra & $\mathrm{pH}(0.551 ; 73)$ & $\mathrm{CO}_{3}^{2-}(0.528 ; 73)$ & $\mathrm{PO}_{4}^{3-}(-0.399 ; 74)$ & $0-100 \mathrm{~m}$ & $\mathrm{E}$ \\
\hline S. protrudens & $\mathrm{pH}(0.557 ; 73)$ & $\mathrm{CO}_{3}^{2-}(0.489 ; 73)$ & $\mathrm{PO}_{4}^{3-}(-0.450 ; 74)$ & Above $50 \mathrm{~m}$ & E \\
\hline F. profunda & $\mathrm{NO}_{3}^{-}+\mathrm{NO}_{2}^{-}(0.637 ; 81)$, & Temperature $(-0.553 ; 81)$ & $\mathrm{pH}(-0.468 ; 73)$ & Below $50 \mathrm{~m}$ & W-E \\
\hline G. flabellatus & $\mathrm{NO}_{3}^{-}+\mathrm{NO}_{2}^{-}(0.583 ; 81)$ & Temperature $(-0.522 ; 81)$ & $\mathrm{O}_{2}(-0.481 ; 73)$ & Below $50 \mathrm{~m}$ & W-E \\
\hline S. pulchra $\mathrm{HOL}$ & $\mathrm{PO}_{4}^{3-}(-0.308 ; 74)$ & $\mathrm{CO}_{2}(-0.261 ; 73)$ & $\mathrm{O}_{2}(0.260 ; 73)$ & Above $50 \mathrm{~m}$ & W-E \\
\hline C. mediterranea & $\mathrm{HCO}_{3}^{-}(-0.294 ; 73)$ & - & - & Above $50 \mathrm{~m}$ & W-E \\
\hline C. mediterranea $\mathrm{HOL}$ & $\mathrm{O}_{2}(0.240 ; 73)$ & - & - & Above $50 \mathrm{~m}$ & W-E \\
\hline H. carteri & $\mathrm{CO}_{2}(0.341 ; 73)$ & $\mathrm{pH}(-0.339 ; 73)$ & - & $0-100 \mathrm{~m}$ & W-E \\
\hline H. carteri $\mathrm{HOL}$ & $\mathrm{NO}_{3}^{-}+\mathrm{NO}_{2}^{-}(-0.284 ; 81)$ & - & - & Above $50 \mathrm{~m}$ & W-E \\
\hline Hetero-abund. & $\mathrm{CO}_{2}(-0.278 ; 73)$ & - & - & $0-100 \mathrm{~m}$ & W-E \\
\hline Holo-abund. & Depth $(-0.427 ; 81)$, & $\mathrm{NO}_{3}^{-}+\mathrm{NO}_{2}^{-}(-0.391 ; 81)$ & $\mathrm{CO}_{2}(0.339 ; 73)$ & Above $50 \mathrm{~m}$ & $\mathrm{E}$ \\
\hline Hetero-diversity (H') & $\mathrm{CO}_{3}^{2-}(-0.486 ; 73)$ & Salinity $(-0.426 ; 81)$ & $\mathrm{pH}(-0.413 ; 73)$ & - & - \\
\hline Holo-diversity (H') & $\mathrm{HCO}_{3}^{-}(-0.460 ; 74)$ & $\mathrm{CO}_{3}^{2-}(0.446 ; 73)$ & $\mathrm{pH}(0.388 ; 73)$ & - & - \\
\hline Diatoms & $\mathrm{CO}_{3}^{2-}(-0.617 ; 73)$ & $\mathrm{pH}(-0.602 ; 73)$ & $\mathrm{PO}_{4}^{3-}(0.534 ; 74)$ & Below $25 \mathrm{~m}$ & $\mathrm{~W}$ \\
\hline Silicoflagellates & $\operatorname{Si}(0.254 ; 76)$ & - & 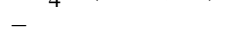 & $0-100 \mathrm{~m}$ & W-E \\
\hline
\end{tabular}

coccolithophores over siliceous phytoplankton, we recorded global and UV radiation at the surface, and at the time of sampling at some of the stations, but lack light data at every depth. No significant correlation was observed for any of the phytoplankton groups with radiation data $(p>0.05$, $N=21)$. Most likely, a response to changes in radiation will not be immediate (specially because the variable that we recorded - cell densities - relates to cell division). In such a case the short temporal extension of our data (by minute during the sampling) could mask a correlation. Large variations in light are also observed on the vertical profile. Holococcolithophores and diatoms correlated with depth (negative and positive correlations, respectively), although for diatoms this correlation was rather weak $(\rho=0.240 ; p=0.031)$. This could indicate that the two groups are more sensitive to light conditions than heterococcolithophores, but it might also be an artifact of the co-correlation between depth and nutrients. Additionally, light attenuation can differ between stations, and therefore this comparison is only approximate.

In the case of nutrients, it is important to notice that the dominance of coccolithophores over siliceous phytoplankton was clear in all the basins, including the Gibraltar strait, where nitrate and phosphate were available and silicate concentrations were above the half-saturation constant for di- atoms (Ks_Si: ca. $3.5 \mu \mathrm{M}$ (Merico et al., 2006; Leblanc et al., 2003; Sarthou et al., 2005) or $0.8-2.3 \mu \mathrm{M}$ (Nelson et al., 1976)) and we could have expected the community to be dominated by fast-growing phytoplankton. In the interior of the Mediterranean, [Si] was probably too low (often below $1.0 \mu \mathrm{mol} \mathrm{Kg}^{-1}$ ) to support large diatom populations, except for the deeper layers $(100 \mathrm{~m})$ of the Ionian and Levantine basins, which ranged from 0.8 to $1.4 \mu \mathrm{mol} \mathrm{Kg}{ }^{-1}$. Egge and Aksnes (1992) observed that, at Si values lower than $0.6 \mu \mathrm{M}$, Emiliania huxleyi outcompeted the otherwise dominant Skeletonema costatum. For the data set here presented, nutrient variability alone does not explain the dominance of coccolithophores during April 2011, at least not directly. A possible phosphate limitation for other phytoplankton groups (notice the high $\mathrm{N} / \mathrm{P}$ ratios in both the eastern and western basins as well as in the Strait of Gibraltar) cannot be ruled out for explaining coccolithophore dominance over other groups. Turbulence does not account for it either, since coccolithophores dominated in regions where water density was homogeneous throughout the first $100 \mathrm{~m}$ as well as in regions where isoclines can be distinguished (e.g., see salinity and temperature profiles from Fig. 2). Overall, the reason for the dominance of coccolithophores over siliceous phytoplankton remains unclear. 
We suggest that the relative success of coccolithophores over siliceous phytoplankton during April 2011 in all Mediterranean Sea basins can be due to a parameter(s) not measured during this study or to a threshold concentration in a resource that limits the growth of the other phytoplankton groups, but that covers the requirements of coccolithophores. The last hypothesis would be better tested experimentally than by correlation analysis.

\subsection{Environmental factors controlling coccolithophore distribution}

Concerning the coccolithophore community, the study of Knappertsbusch (1993) suggests the occurrence of seasonal variability. His sampling was divided in two periods: late winter (February-March 1988) and late summer (September-October 1986). Knappertsbusch observed higher cell densities during late winter and increasing towards the eastern Mediterranean, reaching 230000 cells per liter in the Levantine Basin. During September-October this pattern was reversed. Our results resemble those corresponding to September-October in Knappertsbusch work. However, there was no gradual increase towards the west but rather localized higher cell densities close to Gibraltar and a continuous presence, at lower cell densities, in the rest of the Mediterranean (Fig. 4). This is in agreement with the relatively low satellite-derived chlorophyll $a$ values in most the surface Mediterranean Sea during the month of April, $\sim 0 \mathrm{mg} \mathrm{m}^{-3}$, and the increased values approaching the Strait of Gibraltar, $\sim 0.5-0.6 \mathrm{mg} \mathrm{m}^{-3}$ (Fig. 3), and measured data from Rahav et al. (2013) ranging from $\sim 0.03$ to $\sim 0.1 \mu \mathrm{g} \mathrm{L}^{-1}$ in most of the Mediterranean and rising to $0.31 \mu \mathrm{g} \mathrm{L}^{-1}$ near the Strait of Gibraltar. It also agrees with the suggested modulation of $\mathrm{pH}$ by primary production in the western basin during the cruise (Álvarez et al., 2014). In the study by Ignatiades et al. (2009), the increase in coccolithophore cell densities in the western Mediterranean is mainly due to the significantly higher values at one station (close to the Balearic Islands).

Coccolithophores have a heteromorphic life cycle, with diploid cells producing heterococcoliths and haploid cells producing holococcoliths. Nothing is known about the effects of the ongoing climate change and ocean acidification on coccolithophore life cycle and how this could determine its distribution.

\subsubsection{Holococcolithophores}

Our findings documented that holococcolithophore distribution during the time of the M84/3 cruise was best explained by changes in nutrients $\left(\left[\mathrm{NO}_{3}+\mathrm{NO}_{2}\right]\right.$ and $\left.\left[\mathrm{PO}_{4}^{3-}\right]\right)$ and $\mathrm{pH}(\rho=0.328$, Table 3$)$. They were more abundant in low-nutrient, high-pH seawaters typical of the surface (upper $50 \mathrm{~m}$ ) Mediterranean waters. Holococcolithophores were, in general, present in all samples collected in Mediter-

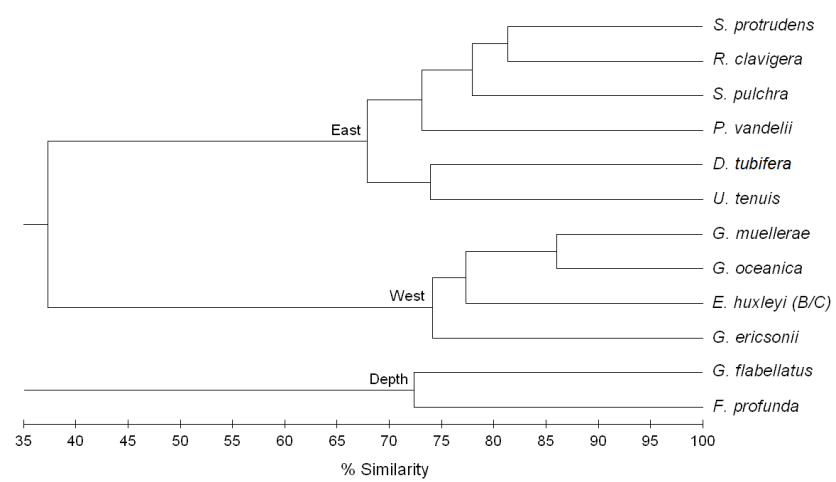

Figure 5. Hierarchical cluster for the heterococcolithophore species that shared more than $65 \%$ similarity in their abundance and distribution patterns.

ranean surface waters but almost absent at deeper depths $(\sim 100 \mathrm{~m})$. Higher abundances in very oligotrophic waters of the Mediterranean Sea have been reported before (Kleijne, 1991,1992). Cros and Estrada (2013) reported holococcolithophores being more abundant in the upper photic zone nutrient-depleted waters. They linked the observed segregation to a differentiation of ecological niches. Dimiza et al. (2008) observed that holococcolithophores around Andros Island were more abundant in surface waters together with some heterococcolithophore species such as Rabdosphaera clavigera. The lower $\rho$ obtained in the BIOENV analysis for holococcolithophores (Table 2) might be due to the lack, in the statistical analysis, of an important parameter (e.g., irradiance, zooplankton grazing) not measured during this study.

Interestingly, when both life phases were recorded (i.e., in the species $S$. pulchra, $C$. mediterranea and $H$. carteri), the environmental factors controlling the abundances were considerably different (Table 4). This clearly indicates that the two life phases respond differently to environmental factors which is likely imposing a differential distribution.

\subsubsection{Heterococcolithophores}

Heterococcolithophore distribution was best linked to a combination of $\left[\mathrm{CO}_{3}^{2-}\right], \mathrm{pH}$, and salinity $(\rho=0.566$; Table 3$)$, and the single abiotic parameter that best grouped heterococcolithophore assemblages in a manner consistent with the sampling locations was $\left[\mathrm{CO}_{3}^{2-}\right]$ (Table 3 , first row). The $\rho$ value for the combination of four variables $-\left[\mathrm{CO}_{3}^{2-}\right] \mathrm{pH}$, salinity, and $\left[\mathrm{PO}_{4}^{3-}\right]$ - was not much lower than the "best fit" ([ $\left.\mathrm{CO}_{3}^{2-}\right] \mathrm{pH}$, salinity). This might indicate that, apart from seawater carbonate chemistry, $\left[\mathrm{PO}_{4}^{3-}\right]$ is also important in explaining heterococcolithophore distribution. It is worth noting that $\left[\mathrm{PO}_{4}^{3-}\right]$ correlated to the heterococcolithophore species diversity $\left(\mathrm{H}^{\prime}\right)(\rho: 0.322, p<0.05)$ but not to the abundance. Thus, the availability of $\mathrm{PO}_{4}^{3-}$ might co- 


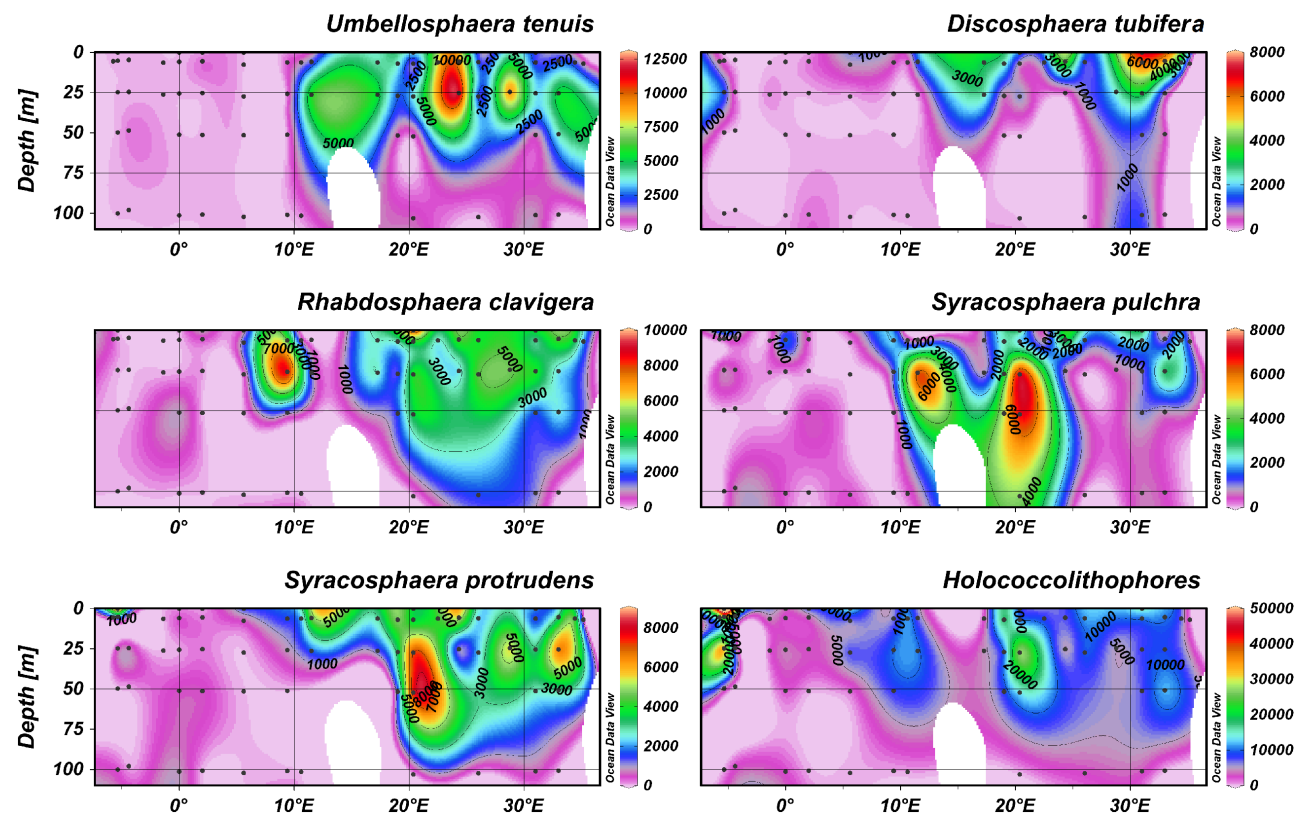

Figure 6. Distribution, along a west-east transect, of the heterococcolithophore species forming the cluster comprised mainly of "eastern Mediterranean species". Holococcolithophores as a group are added in the bottom right panel (the transect includes the stations labeled in black in Fig. 1).
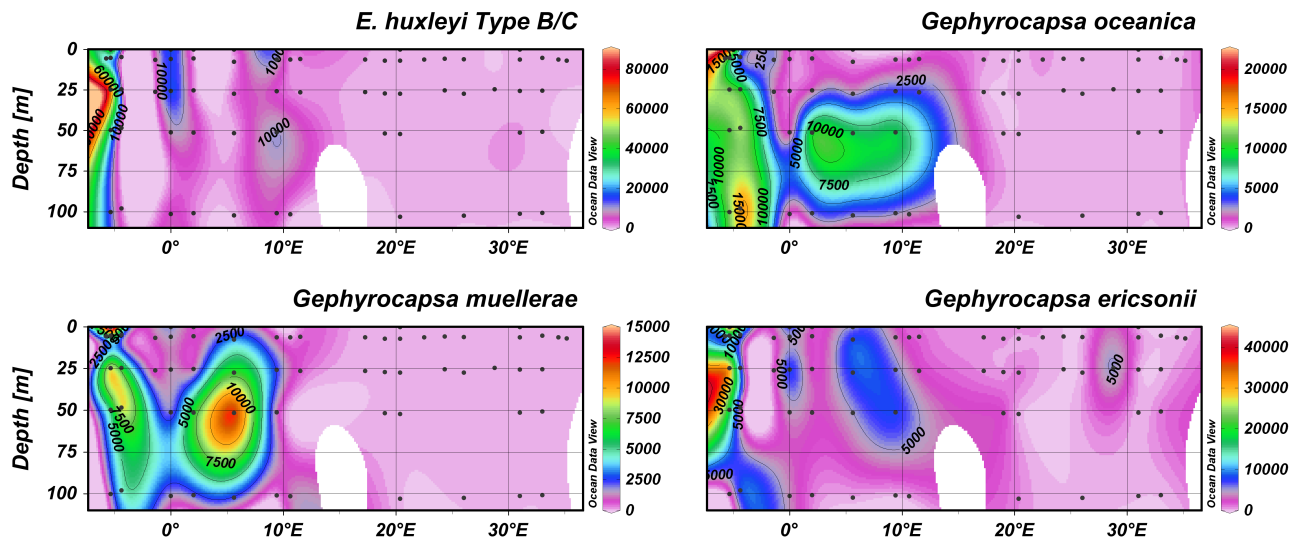

Figure 7. Distribution, along a west-east transect, of the heterococcolithophore species forming the cluster comprised mainly of "western Mediterranean species" (the transect includes the stations labeled in black in Fig. 1).

determine the assemblage composition. Differences in $\mathrm{PO}_{4}^{3-}$ usage have been reported between strains of the same species (Oviedo et al., 2014). It is therefore likely that different species show different sensitivities to $\left[\mathrm{PO}_{4}^{3-}\right]$, which could induce differences in community composition upon environmental $\left[\mathrm{PO}_{4}^{3-}\right]$. Overall, we suggest $\left[\mathrm{CO}_{3}^{2-}\right], \mathrm{pH}$, and probably $\left[\mathrm{PO}_{4}^{3-}\right]$ as functionally related important variables in explaining heterococcolithophore distribution in the Mediterranean Sea.

Although heterococcolithophores preferentially use $\mathrm{HCO}_{3}^{-}$for their intracellular calcification within a calcifying vesicle (Mackinder et al., 2010) at alkaline $\mathrm{pH}$ values, $\mathrm{CO}_{3}^{2-}$ is the major carbon source for $\mathrm{CaCO}_{3}$ and we can assume the uptake of both $\mathrm{HCO}_{3}^{-}$and $\mathrm{CO}_{3}^{2-}$ (Ziveri et al., 2012). In the Mediterranean Sea, $\left[\mathrm{CO}_{3}^{2-}\right]$ increases gradually towards the east. Thus, it is possible that those species thriving in the eastern basins utilize comparatively more $\mathrm{CO}_{3}^{2-}$ than those that prosper in the western Mediterranean. Using a compilation from worldwide plankton samples and sediments spanning the last $40 \mathrm{kyr}$, Beaufort et al. (2011) recorded significant correlations between coccolith mass belonging to the family Noelaerhabdaceae (genera Emiliania, Gephyrocapsa, and Reticulofenestra) with $\left[\mathrm{CO}_{3}^{2-}\right]$ and $\left[\mathrm{HCO}_{3}^{-}\right]$. They argue that differentially calcified species are distributed in the ocean according to the ocean's carbonate 


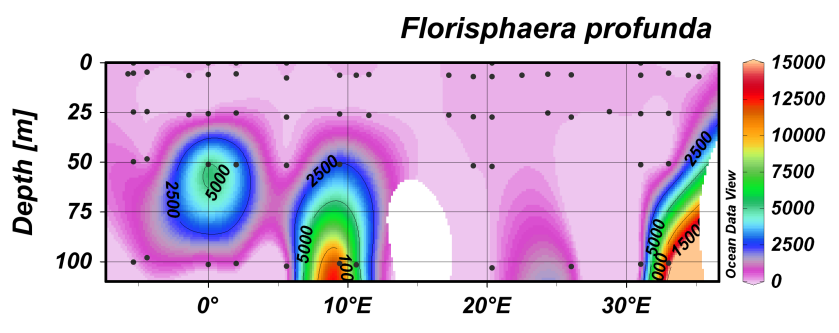

Gladiolithus flabellatus

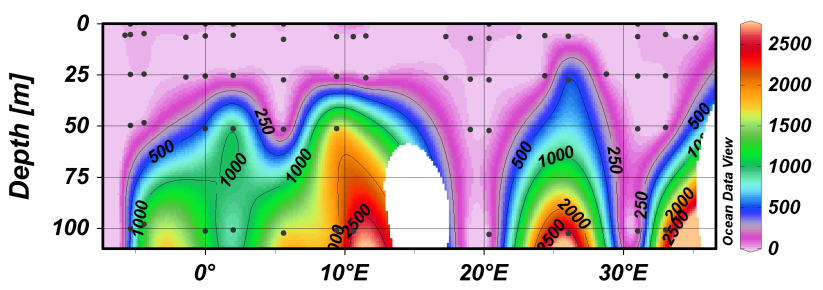

Figure 8. Distribution, along a west-east transect, of the heterococcolithophore species forming the smallest of the observed clusters comprised of two deep photic zone species (the transect includes the stations labeled in black in Fig. 1).
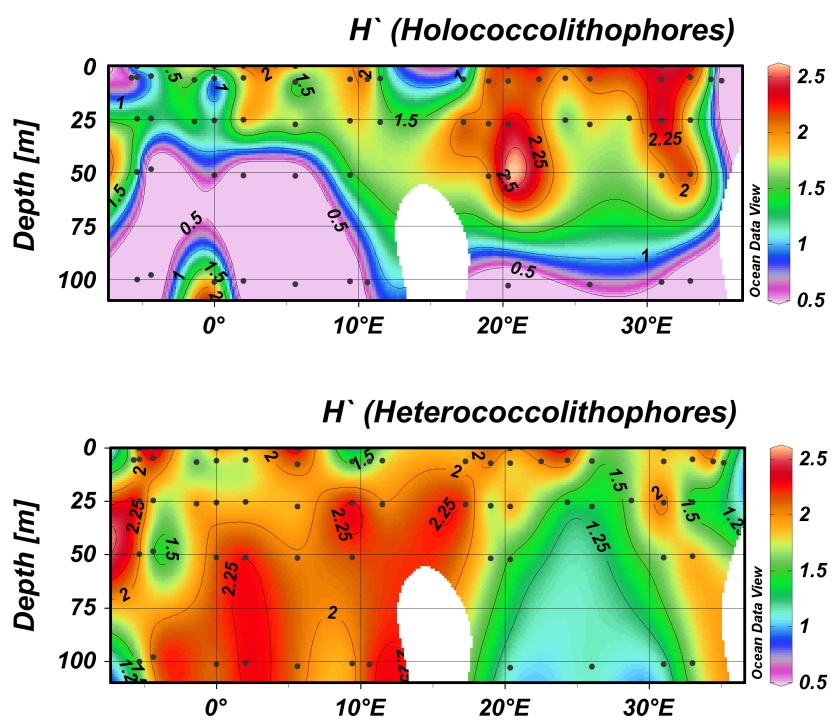

Figure 9. Shannon-Wiener diversity index for holococcolithophores and heterococcolithophores. A higher index, or higher uncertainty in correctly guessing the "next species" that would be sampled, is representative of a more diverse community.

chemistry. Modeling studies also highlighted the importance of $\left[\mathrm{CO}_{3}^{2-}\right]$ for coccolithophore distribution, as observed by Merico et al. (2006); Tyrell et al. (2008) observed that Emiliania huxleyi blooms in the Baltic Sea coincide with periods of high $\left[\mathrm{CO}_{3}^{2-}\right]$.

Changes in $\mathrm{pH}$ are concomitant with changes in the ratio between bicarbonate and carbonate ions. This makes difficult to disentangle which parameter of the carbonate system could affect coccolithophore populations. Under laboratory culture conditions, Emiliania huxleyi calcification is sensitive to low $\mathrm{pH}$ and bicarbonate, while photosynthesis and growth is sensitive to low $p \mathrm{CO}_{2}$ (Bach et al., 2013) and the coccolith morphogenesis in Calcidiscus leptoporus is hampered by $p \mathrm{CO}_{2}$ and no other parameter of the carbonate chemistry (Langer and Bode, 2011). How will these responses translate to a community scale in the ocean? Charalampopoulou et al. (2011) found that the coccolithophore species distribution between the North Sea and the Atlantic Ocean related to $\mathrm{pH}$ and irradiance. In our study, $p \mathrm{CO}_{2}$, one of the parameters considered to run the BIOENV routine, was not part of the best-fitting variables to explain coccolithophore distribution patterns. This might be an indication that, during the time of the study, there was no evident $p \mathrm{CO}_{2}$ limitation of photosynthesis in the observed species or that coccolithophore sensitivity to $\mathrm{CO}_{2}$ among species, even if different (Langer et al., 2006, 2009) do not have major effects on coccolithophore species assemblages in the Mediterranean. Imitating the experimental design of the abovementioned culture experiments on a mesocosm scale could help elucidating how the different effects of carbonate chemistry modification on coccolithophore's physiology and morphology will shape the community.

Salinity, even if one of the environmental variables that optimized the best-fitting combination of variables explaining the biological data, might not be crucial in controlling heterococcolithophore distribution. Experimental evidence (Brand, 1984) indicates strain-specific differences that allow Emiliania huxleyi to survive at a wide salinity range. E. huxleyi has been found in oceanographic regions characterized by very different salinities (reviewed by Tyrrell et al., 2008). Furthermore, heterococcolithophores isolated from the Mediterranean Sea (CODENET collection) were maintained at salinities of 32-33 with non-observed adverse effects (Probert and Houdan, 2004).

\subsection{Species assemblages}

Another feature that was different between the coccolithophore life stages is the development of species assemblages. Holococcolithophore species did not form different assemblages along the Mediterranean Sea (no species clustering with high similarities in abundance and distribution). Holococcolithophores seem to behave as a homogeneous group, exploiting a similar ecological niche. However, three heterococcolith clusters were identified whose species shared more than $65 \%$ similarities (Fig. 5). The first group comprises species that were more abundant in the eastern stations: U. tenuis, D. tubifera, P. vandelii, S. pulchra, $R$. clavigera, and $S$. protrudens. The second group includes $E$. huxleyi Type B/C and the Gephyrocapsa species - G. ericsonii, G. muellerae, and G. oceanica - that were almost exclusive to the western Mediterranean. A third group was formed by Florisphaera profunda and Gladiolithus flabellatus and found with higher abundances below $50 \mathrm{~m}$. Most of the species in these clusters have been found to share 
an ecological niche in other studies: U. tenuis, D. tubifera, $S$. pulchra, and R. clavigera have been considered typical in oligotrophic warm waters and/or surface water species (Okada and Honjo 1973; Okada and McIntyre, 1977, 1979; Nishida, 1979; Ziveri et al., 2000; Haidar and Thierstein, 2001; Malinverno et al., 2003; Ziveri et al., 2004, for Syracosphaera spp.; Triantaphyllou et al., 2004). The gephyrocapside species have been considered typical of eutrophic areas (Kleijne, 1989; Broerse et al., 2000) with lower density, lower salinity and higher temperature (Takahashi and Okada, 2000; Knappertsbusch, 1993). Finally, F. profunda and G. flabellatus are widely recognized deep euphotic zone species, often living below $100 \mathrm{~m}$ depth (Okada and Honjo, 1973; Boeckel et al., 2006), and are controlled by the dynamics of the nutricline and thermocline (Molfino and McIntyre, 1990; Triantaphyllou et al., 2004). Both species were an important component below the $50 \mathrm{~m}$, with highest abundances around $100 \mathrm{~m}$, where fluorescence data (not shown) place the deep chlorophyll maximum. The positive correlation with $\left[\mathrm{NO}_{3}+\right.$ $\mathrm{NO}_{2}$ ] supports the previous observations. The negative correlation with temperature reflects the fact that nutrients are generally linked to deep mixing and colder waters. For instance, higher abundances of $F$. profunda have been observed in sediments underneath relatively warmer and stratified surface waters with a deep nutricline (Boeckel et al., 2006).

The clustering of coccolithophore species resembles those proposed by Young (1994): an umbelliform group such as Umbellosphaera tenuis, found in nutrient-depleted waters; a second group of placolith-bearing cells such as Emiliania huxleyi or Gephyrocapsa spp. found in coastal or midocean upwelling regions; and a last group, composed of floriform cells, such as Florisphaera profunda, associated with deep photic-zone assemblages in low to mid-latitudes. To the first group we would add the rabdolith-bearing species as well as some Syracosphaera species widely associated with oligotrophic (Ziveri et al., 2004) surface waters (Malinverno et al., 2003) and cluster them together in our study. As Balch (2004) suggested when referring to this species grouping proposed by Young, "it is likely that the three groups of coccolithophores show differences in their growth strategies which ultimately would relate to their natural abundance".

Heterococcolithophores and holococcolithophores also displayed opposite trends in species diversity (Fig. 9). However the weak correlation obtained between the diversity index H' and the longitude of the sample site should be taken into account. Given the taxonomical problems between the two life stages (see Sect. 2.1) when considering the two as a single group would lead to the overestimation of the number of species, affecting H'. Future work on the topic of discriminating between the two life stages would be necessary in order to clarify the trends suggested here.

Overall, distribution patterns and their relation to environmental parameters are different between the holo- and heterococcolithophore life phases. This is probably the result of a different physiology and reveals that the two phases are ex- ploiting different ecological niches. Differences in the morphology and ecology of the two life phases enable the species to survive under a wider range of environmental conditions and could result in a wider distribution range in space and/or time. For instance, blooms of Emiliania huxleyi in heterococcolith phase can end due to viral attacks (Martínez et al., 2007; Vardi et al., 2012) which the haploid phase (i.e., holococcolithophores) can resist (Frada et al., 2008, 2012): Therefore, the occurrence of haploid individuals would serve as new starting point in the case of viral attack in the heterococcolith phase. Another factor that could have affected the results presented here is zooplankton grazing: although generally zooplankton grazing does not cause $E$. huxleyi blooms to end (Nejstgaard et al., 1997), their effect on smaller populations could be more important. Possibly important factors that were not addressed in our study are zooplankton grazing and irradiance. Therefore, their contribution to the control of the observed distribution of holo- and heterococcolith life phases cannot be ruled out.

\subsubsection{Gephyrocapsa oceanica, G. muellerae, and Emiliania huxleyi morphotype $\mathrm{B} / \mathrm{C}$ as tracers of Atlantic water influx}

Atlantic Water (AW), with a winter salinity around 36.5 (Rohling, 2009), enter the Mediterranean Sea through the Strait of Gibraltar. In its eastwards pathway following a cyclonic circulation, the surface water increases in salinity, TA, and temperature and decreases in nutrient concentrations. A main part of this AW flows into the Tyrrhenian Sea (Tanhua et al., 2013b, and references therein). Therefore, if there are species that arrive within this water mass (but whose optimal environment is not typical of eastern Mediterranean waters), the Tyrrhenian Sea could still host them.

During April 2011, the distribution of the species Gephyrocapsa oceanica and $G$. muellerae and morphotype B/C of the species Emiliania huxleyi was highly and negatively correlated with salinity. We have argued that salinity constrain to coccolithophore distribution is not critical. A high correlation with this parameter might just reflect the carry-over of a different species assemblage in a different water mass. Gephyrocapsa oceanica, G. muellerae, and morphotype B/C of the species Emiliania huxleyi were mostly present until $\sim 10^{\circ} \mathrm{E}$ after the Sardinia Channel and in the Tyrrhenian Sea. They are all present in AW (Ziveri et al., 2004; McIntyre and Bé, 1967) and have been reported before for western Mediterranean waters (e.g., Cross, 2002, and Knappertsbusch, 1993; the latter only for Gephyrocapsa spp). The morphotype B/C of E. huxleyi has been associated with cold (Hagino et al., 2005; Mohan et al., 2008), nutrientrich ( $>10 \mu \mathrm{mol}$ nitrate $\mathrm{kg}^{-1}$ ) waters with low calcite saturation states. These characteristics can be found in AW but are lost very soon in the Mediterranean Sea. Knappertsbusch (1993) related G. oceanica to surface AW's influence given the highly negative correlation with salinity. Here we 
propose Gephyrocapsa oceanica, G. muellerae, and Emiliania huxleyi morphotype $\mathrm{B} / \mathrm{C}$ as tracers for $\mathrm{AW}$ influx into the Mediterranean.

\section{Conclusions}

Our results highlight the importance of seawater carbonate chemistry, especially $\left[\mathrm{CO}_{3}^{2-}\right]$, and $\left[\mathrm{PO}_{4}^{3-}\right]$ in unraveling the distribution of heterococcolithophores, the most abundant coccolithophore life stage. Thus, carbonate system parameters might be critical, but overlooked, for solving the coccolithophore distribution patterns. In contrast, holococcolithophore distribution was mainly linked to oligotrophic conditions. This correlation can be due to competitive advantages under such conditions, but this hypothesis remains to be tested.
Environmental parameters that drive the observed patterns in distribution and assemblage composition of the haploid and diploid life phases of coccolithophores (holo- and heterococcolithophore) differ. Our results emphasize the importance of considering holo- and heterococcolithophores separately when analyzing changes in species assemblages and diversity, and the impacts of acidification on coccolithophores. Changes in the biogeographic distribution of hetero- and holococcolithophores can be expected along with the changes in carbonate chemistry and nutrient concentrations that are projected for the next century. 


\section{Appendix A}

Table A1. Coccolithophore species list. Heterococcolithophores.

\begin{tabular}{l}
\hline [1] Anoplosolenia brasiliensis (Lohmann) Deflandre \\
[2] Calciosolenia murrayi Gran \\
\hline Family Coccolithaceae Poche \\
\hline [3] Calcidiscus leptoporus (Murray et Blackman) Loeblich et Tappan \\
[4] Hayaster perplexus (Bramlette et Riedel) Bukry \\
[5] Pleurochrysis carterae (Braarud et Fagerland) Christensen \\
[6] Umbilicosphaera sibogae var. sibogae (Weber-Van Bosse) Gaarder \\
[7] U. foliosa (Kamptner) Geisen \\
[8] U. hulburtiana Gaarder \\
\hline Family Helicosphaeraceae Black \\
\hline [9] Helicosphaera carteri (Wallich) Kamptner \\
[10] H. pavimentum Okada et McIntire \\
\hline Family Noelaerhabdaceae Jerkovic \\
\hline [11] Emiliania huxleyi (Lohmann) Hay et Mohler \\
[12] Gephyrocapsa ericsonii McIntire et Bé \\
[13] G. ornata Heimdal \\
[14] G. oceanica Kamptner \\
[15] G. muellerae Bréhéret \\
[16] Reticulofenestra parvula (Okada et McIntyre) Biekart
\end{tabular}

Family Papposphaeraceae Jordan et Young

[17] Papposphaera lepida Tangen

Family Pontosphaeraceae Lemmermann

[18] Pontosphaera japonica (Takayama) Nishida

[19] Scyphosphaera apsteinii Lohmann

Family Rhabdoaphaeraceae Ostenfeld

[20] Acanthoica biscayensis Kleijne

[21] A. quattrospina Lohmann

[22] Algirosphaera cucullata (Lecal-Schlauder) Young, Probert et Kleijne

[23] Algiropsphaera robusta (Lohmann) Norris

[24] Anacanthoica acanthos (Schiller) Deflandre

[25] Cyrtosphaera lecaliae Kleijne

[26] Discosphaera tubifera (Murray et Blackman) Ostenfeld

[27] Palusphaera vandeli Lecal emend. Norris

[28] Rhabdosphaera clavigera var. clavigera Murray et Blackman

[29] $R$. clavigera var. stylifera (Lohmann) Kleijne et Jordan

[30] R. xiphos (Deflandre et Fert) Norris

Family Syracosphaeraceae Lemmermann

[31] Alisphaera capulata Heimdal

[32] A. extentata (Kamptner) Kleijne, Jordan, Heimdal, Samtleben, Chamberlain et Cros

[33] A. gaudi (Kamptner) Kleijne, Jordan, Heimdal, Samtleben, Chamberlain et Cros

[34] A. unicornis Okada et McIntire

[35] Calciopappus caudatus Gaarder et Ramsfjell

[36] C. rigidus Heimdal 
Table A1. Continued.

[37] Coronosphaera binodata (Kamptner) Gaarder

[38] C. mediterranea (Lohmann) Gaarder

[39] Michaelsarsia adriaticus (Schiller) Manton, Bremer et Oates

[40] M. elegans Gran, emend. Manton, Bremer et Oates

[41] Ophiaster formosus Gran

[42] Ophiaster hydroideus Gran

[43] Syracosphaera ampliora Okada et McIntire

[44] S. anthos (Lohmann) Jordan et Young

[45] S. bannockii (Borsetti et Cati) Cros, Kleijne, Zeltner, Billard et Young

[46] S. borealis Okada et McIntire

[47] S. corolla Lecal

[48] S. delicata Cros, Kleijne, Zeltner, Billard et Young

[49] S.dilatata Jordan, Kleijne et Heimdal

[50] S. histrica Kamptner

[51] S. lamina Lecal-Schlauder

[52] S. marginoporata Knappertsbusch

[53] S. molischii Schiller

[54] S. nana (Kamptner) Okada et McIntyre

[55] S. nodosa Kamptner

[56] S. noroitica Knappertsbusch

[57] S. ossa (Lecal) Loeblich et Tappan

[58] S. pirus Halldal et Markali

[59] S. prolongata Gran, ex Lohmann

[60] S. protrudens Okada et McIntyre

[61] S. pulchra Lohmann

[62] S. rotula Okada et McIntire

[63] Syracosphaera sp. type D, sensu Kleijne

[64] S. tumularis Sánchez- Suárez

[65] Syracospahaera sp.

Sub-Family Umbellosphaeroideae Kleijne

[66] Umbellosphaera tenuis (Kamptner) Paasche

[67] F. profunda Okada et Honjo

[68] Gladiolithus flabellatus (Halldal et Markali) Jordan et Green

[69] Polycrater galapagensis Manton et Oates

[70] Ceratolithus cristatus Norris 
Table A2. Coccolithophore species list. Holococcolithophores.

[1] Acanthoica quattrospina $\mathrm{HOL}=\mathrm{sp}$. aff Sphaerocalyptra of Cros et al. (2000)

[2] Anthosphaera fragaria Kamptner emend. Kleijne

[3] A. lafourcadii (Lecal) Kleijne

[4] A. periperforata Kleijne

[5] Anthosphaera sp. Type A of Cros and Fortuño (2002)

[6] Anthosphaera sp. Type C of Cros and Fortuño (2002)

[7] Calcidiscus leptoporus HOL (Murray et Blackman) Loeblich et Tappan

[8] C. leptoporus ssp. quadriperforatus HOL (Kamptner) Geisen, Billard, Broerse, Cros, Probert et Young

[9] Calicasphaera concava Kleijne

[10] Calyptrolithina divergens (Halldal et Markali) Heimdal

[11] C. divergens var. tuberosa (Heimdal) Jordan, Kleijne et Heimdal

[12] C. multipora (Gaarder) Norris

[13] Calyptrolithophora papillifera (Halldal) Heimdal

[14] Calyptrosphaera cialdii Borsetti et Cati

[15] C. dentata Kleijne

[16] C. heimdalae Norris

[17] C. sphaeroidea Schiller

[18] Coccolithus pelagicus ssp. braarudii HOL (Gaarder) Geisen, Billard, Broerse, Cros, Probert et Young

[19] Corisphaera gracilis Kamptner

[20] C. strigilis Gaarder

[21] C. tyrrheniensis Kleijne

[22] Corisphaera sp. Type A of Kleijne (1991)

[23] Coronosphaera mediterranea HOL gracillima-type =Calyptrolithophora gracillima (Kamptner) Heimdal

[24] Coronosphaera mediterranea HOL hellenica-type =Zygosphaera hellenica Kamptner

[25] Gliskolithus amitakarenae Norris, orthog. emend., Jordan et Green

[26] Helicosphaera carteri HOL =Syracolithus catilliferus (Kamptner) Deflandre

[27] Helladosphaera cornifera (Schiller) Kamptner

[28] Homozygosphaera arethusae (Kamptner) Kleijne

[29] H. spinosa (Kamptner) Deflandre

[30] H. triarcha Halldal et Markalii

[31] Homozygosphaera vercellii Borsetti et Cati

[32] Poricalyptra gaarderae (Borsetti et Cati) Kleijne

[33] Poritectolithus sp. 2 of Cros and Fortuño (2002)

[34] Sphaerocalyptra adenensis Kleijne

[35] S. quadridentata (Schiller) Deflandre

[36] Sphaerocalyptra sp. 1 of Cros and Fortuño (2002)

[37] Sphaerocalyptra sp. 3 of Cros and Fortuño (2002)

[38] Sphaerocalyptra sp. 6 of Cros and Fortuño (2002)

[39] Syracolithus schilleri (Kamptner) Loeblich et Tappan

[40] Syracolithus sp. type A of Kleijne (1991)

[41] Syracosphaera anthos $\mathrm{HOL}=$ Periphyllophora mirabilis (Schiller) Kamptner

[42] Syracosphaera bannockii HOL =Zygosphaera bannockii (Borsetti et Cati) Heimdal

[43] Syracosphaera pulchra HOL oblonga-type =Calyptrosphaera oblonga Lohmann

[44] Syracosphaera pulchra HOL pirus-type =Calyptrosphaera pirus Kamptner

[45] Zygosphaera amoena Kamptner 
Acknowledgements. We thank the crew members and scientists onboard the R/V Meteor during the M84/3 campaign for making a month of sampling possible and a warm and welcoming time onboard. Thanks to Vincent Taillandier for helping with the chlorophyll data. This work was partially funded by the European Community's Seventh Framework Programme under grant agreement 265103 (project MedSeA) and by project HOTMIX (CTM2011-30010-C02). The authors also acknowledge the "Agencia de Gestión de Ayudas Universitarias y de Investigación” (Becas FI) of the Catalunya Generalitat. We thank Sebastian Meier and the anonymous reviewer for their comments that greatly enriched the manuscript.

Edited by: N. Kress

\section{References}

Álvarez, M., Sanleón-Bartolomé, H., Tanhua, T., Mintrop, L., Luchetta, A., Cantoni, C., Schroeder, K., and Civitarese, G.: The $\mathrm{CO}_{2}$ system in the Mediterranean Sea: a basin wide perspective, Ocean Sci., 10, 69-92, doi:10.5194/os-10-69-2014, 2014.

Bach, L. T., Mackinder, L. C., Schulz, K. G., Wheeler, G., Schroeder, D. C., Brownlee, C. and Riebesell, U.: Dissecting the impact of $\mathrm{CO}_{2}$ and $\mathrm{pH}$ on the mechanisms of photosynthesis and calcification in the coccolithophore Emiliania huxleyi, New Phytol., 199, 121-134, doi:10.1111/nph.12225, 2013.

Balch, W. M.: Re-evaluation of the physiological ecology of coccolithophores, in: Coccolithophores - From Molecular Processes to Global Impact, edited by: Thierstein, H. and Young, J. R., Springer, Berlin, 165-190, 2004.

Bakun, A. and Agostini, V. N.: Seasonal patterns of wind-induced up- welling/downwelling in the Mediterranean Sea, Sciencia Marina, 65, 243-257, 2001.

Barcena, M. A., Flores, J. A., Sierro, F. J., Pérez-Folgado, M., Fabres, J., Calafat, A., and Canals, M.: Planktonic response to main oceanographic changes in the Alboran Sea (Western Mediterranean) as documented in sediment traps and surface sediments, Mar. Micropaleontol., 53, 423-445, 2004.

Barlow, R. G., Mantoura, R. F. C., Cummings, D. G., and Fileman, T. W.: Pigment chemotaxonomic distributions of phytoplankton during summer in the western Mediterranean, Deep-Sea Res. Pt. II, 44, 833-850, doi:10.1016/S0967-0645(96)00089-6, 1997.

Beaufort, L., Couapel, M., Buchet, N., Claustre, H., and Goyet, C.: Calcite production by coccolithophores in the south east Pacific Ocean, Biogeosciences, 5, 1101-1117, doi:10.5194/bg-5-11012008, 2008.

Beaufort, L., Probert, I., de Garidel-Thoron, T., Bendif, E. M., RuizPino, D., Metzl, N., Goyet, C., Buchet, N., Coupel, P., Grelaud, M., Rost, B., Rickaby, R. E. M., and de Vargas, C.: Sensitivity of coccolithophores to carbonate chemistry and ocean acidification, Nature, 476, 80-83, 2011.

Berland, B. R., Benzhitski, A. G., Burlakova, Z. P., Georgieva, L. V., Izmestieva, M. A., Kholodov, V. I., and Maestrini, S. Y.: Conditions hydrologiques estivales en Mediterranee, repartition du phytoplankton et de la matiere organique, Oceanol. Acta, 9, 163$177,1988$.

Berman, T., Townsend, D. W., El Sayed, S. Z., Trees, G. C., and Azov, Y.: Optical transparency, chlorophyll and primary pro- ductivity in the Eastern Mediterranean near the Israeli Coast, Oceanol. Acta, 7, 367-372, 1984.

Boeckel, B., Baumann, K. H., Henrich, R., and Kinkel, H.: Coccolith distribution patterns in South Atlantic and Southern Ocean surface sediments in relation to environmental gradients, DeepSea Res. Pt. I, 53, 1073-1099, doi:10.1016/j.dsr.2005.11.006, 2006.

Brand, L. E.: The salinity tolerance of forty-six marine phytoplankton isolates, Estuar. Coast. Shelf S., 18, 543-556, 1984.

Brand, L. E.: Physiological ecology of marine coccolithophores, in: Coccolithophores, edited by: Winter, A. and Siesser, W. G., Cambridge University Press, UK, 39-49, 1994.

Broerse, A. T. C., Brummer, G.-J. A., and Van Hinte, J. E.: Coccolithophore export production in response to monsoonal upwelling off Somalia (northwestern Indian Ocean), Deep-Sea Res. Pt. II, 47, 2179-2205, 2000.

Charalampopoulou, A., Poulton, A. J., Tyrrell, T., and Lucas, M. I.: Irradiance and $\mathrm{pH}$ affect coccolithophore community composition on a transect between the North Sea and the Arctic Ocean, Mar. Ecol.-Prog. Ser., 431, 25-43, 2011.

Cortès, M. Y., Bollman, J., and Thierstein, H. R.: Coccolithophore ecology at the HOT station Aloha, Hawaii, Deep-Sea Res. Pt. II, 48, 1957-1981, 2001.

Cros, L.: Planktic coccolithophores of the NW Mediterranean. PhD Thesis, Universitat de Barcelona, Barcelona, 181 pp., 2002.

Cros, L. and Estrada, M.: Holo-heterococcolithophore life cycles: ecological implications, Mar. Ecol.-Prog. Ser., 492, 57-68, 2013.

Cros, L. and Fortuno, J.-M.: Atlas of northwestern Mediterranean coccolithophores, Sci. Mar., 66, 7-182, 2002.

Decembrini, F., Caroppo, C., and Azzaro, M.: Size structure and production of phytoplank- ton community and carbon pathways channelling in the Southern Tyrrhenian Sea (Western Mediterranean), Deep-Sea Res. Pt. II, 56, 687-699, 2009.

Dickson, A. G. and Millero, F. J.: A comparison of the equilibrium constants for the dissociation of carbonic acid in seawater media, Deep-Sea Res., 34, 1733-1743, 1987.

Dimiza, M. D., Triantaphyllou, M. V., and Dermitzakis, M. D.: Vertical distribution and ecology of living coccolithophores in the marine ecosystems of Andros Island (Middle Aegean Sea) during late summer 2001, Hellenic J. Geosci., 43, 7-20, 2008.

Dugdale, R. C. and Wilkerson, F. P.: Nutrient sources and primary production in the eastern Mediterranean, Oceanol. Acta, Special Issue, 9, 179-184, 1988.

Egge, J. K. and Aksnes, D. L.: Silicate as regulating nutrient in phytoplankton competition, Mar. Ecol.-Prog. Ser., 83, 281-289, 1992.

Falkowski, P. G.: The role of phytoplankton photosynthesis in global biogeochemical cycles, Photosynth. Res., 39, 235-258, 1994.

Field, C. B., Behrenfeld, M. J., Randerson, J. T., and Falkowski, P. G.: Primary production of the biosphere: integrating terrestrial and oceanic components, Science, 281, 237-240, 1998.

Frada, M., Probert, I., Allen, M. J., Wilson, W. H., and De Vargas, C.: The "Cheshire Cat" escape strategy of the coccolithophore Emiliania huxleyi in response to viral infection, P. Natl. Acad. Sci. USA, 105, 15944-15949, 2008.

Frada, M. J., Bidle, K. D., Probert, I., and de Vargas, C.: In situ survey of life cycle phases of the coccolithophore Emiliania huxleyi (Haptophyta), Environ. Microbiol., 14, 1558-1569, 2012. 
Gotsis-Skretas, O., Pagou, K., Moraitou-Apostolopoulou, M., and Ignatiades, L.: Seasonal horizontal and vertical variability in primary production and standing stocks of phytoplankton and zooplankton in the Cretan Sea and the Straits of the Cretan Arc (March 1994-January 1995), Prog. Oceanogr., 44, 625-649, 1999.

Hagino, K., Okada, H., and Matsuoka, H: Spatial dynamics of coccolithophore assemblage in the Euatorial Western-Central Pacific Ocean, Mar. Micropaleontol., 39, 53-72, 2000.

Hagino, K., Okada, H., and Matsuoka, H.: Coccolithophore assemblages and morphotypes of Emiliania huxleyi in the boundary zone between the cold Oyashio and warm Kuroshio currents off the coast of Japan, Mar. Micropaleontol., 55, 19-47, 2005.

Haidar, A. T. and Thierstein, H. R.: Coccolithophore dynamics off Bermuda (N. Atlantic), Deep- Sea Res. Pt. II, 40, 1925-1956, 2001.

Hainbucher, D., Rubino, A., Cardin, V., Tanhua, T., Schroeder, K., and Bensi, M.: Hydrographic situation during cruise M84/3 and P414 (spring 2011) in the Mediterranean Sea, Ocean Sci., 10, 669-682, doi:10.5194/os-10-669-2014, 2014.

Ignatiades, L., Georgopoulos, D., and Karydis, M.: Description of the phytoplanktonic community of the oligotrophic waters of the SE Aegean Sea (Mediterranean), Mar. Ecol.-P. S. Z. N. I., 16, 13-26, 1995.

Ignatiades, L., Gotsis-Skretas, O., Pagou, K., and Krasakopoulou, E.: Diversification of phyto- plankton community structure and related parameters along a large-scale longitudinal east-west transect of the Mediterranean Sea, J. Plankton Res., 31, 411-428, 2009.

Kleijne, A.: Holococcolithophorids from the Indian Ocean, Red Sea, Mediterranean Sea and North Atlantic Ocean, Mar. Micropaleontol., 17, 1-76, 1991.

Kleijne, A.: Extant Rhabdosphaeraceae (coccolithophorids, class Prymnesiophyceae) from the Indian Ocean, Red Sea, Mediterranean Sea and North Atlantic Ocean, ScriptaGeol., 100, 1-63, 1992.

Kleijne, A., Kroon, D., and Zevenboom, W.: Phytoplankton and foraminiferal frequencies in northern Indian Ocean and Red Sea surface waters, Neth. J. Sea Res., 24, 531-539, 1989.

Knappertsbusch, M.: Geographic distribution of living and Holocene coccolithophores in the Mediterranean Sea, Mar. Micropaleontol., 21, 219-247, 1993.

Kroeker, K. J., Kordas, R. L., Crim, R., Hendriks, I. E., Ramajo, L., Singh, G. S., Duarte, C. M., and Gattuso, J. P.: Impacts of ocean acidification on marine organisms: quantifying sensitivities and interaction with warming, Glob. Change Biol., 19, 1884-1896, doi:10.1111/gcb.12179, 2013.

Krom, M. D., Kress, N., Brenner, S., and Gordon, L.: Phosphorous limitation of primary productivity in the Eastern Mediterranean Sea, Limnol. Oceanogr., 36, 424-432, 1991.

Langer, G. and Bode, M.: $\mathrm{CO}_{2}$ mediation of adverse effects of seawater acidification in Calcidiscus leptoporus, Geochem. Geophy. Geosy., 12, Q05001, doi:10.1029/2010GC003393, 2011.

Langer, G., Geisen, M., Baumann, K.-H., Kläs, J., Riebesell, U., Thoms, S., and Young, J. R.: Species-specific responses of calcifying algae to changing seawater carbonate chemistry, Geochem. Geophy. Geosy., 7, Q09006, doi:10.1029/2005GC00122, 2006.

Langer, G., Nehrke, G., Probert, I., Ly, J., and Ziveri, P.: Strain-specific responses of Emiliania huxleyi to changing seawater carbonate chemistry, Biogeosciences, 6, 2637-2646, doi:10.5194/bg-6-2637-2009, 2009.

Lasternas, S., Tunin-Ley, A., Ibañez, F., Andersen, V., Pizay, M.D., and Lemée, R.: Short-term dynamics of microplankton abundance and diversity in NW Mediterranean Sea during late summer conditions (DYNAPROC 2 cruise; 2004), Biogeosciences, 8, 743-761, doi:10.5194/bg-8-743-2011, 2011.

Leblanc, K., Quéguiner, B., Garcia, N., Rimmelin, P. and Raimbault, P.: Silicon cycle in the NW Mediterranean Sea: seasonal study of a coastal oligotrophic site, Oceanol. Acta, 26, 339-355, 2003.

Lewis, E. and Wallace, D. W. R: Program developed for $\mathrm{CO}_{2}$ system calculations ORNL/CDIAC-105. Carbon Dioxide Information Analysis CentreOak Ridge National Laboratory, U.S. Department of Energy, Oak Ridge, Tennessee, 1998.

Mackinder, L., Wheeler, G., Schroeder, D., Riebesell, U., and Brownlee, C.: Molecular mechanisms underlying calcification in coccolithophores, Geomicrobiol. J., 27, 585-595, doi:10.1080/01490451003703014, 2010.

Malinverno, E., Ziveri, P., and Corselli, C.: Coccolithophorid distribution in the Ionian Sea and its relationship to eastern Mediterranean circulation during late fall to early winter 1997 , J. Geophys. Res., 108, 8115, doi:10.1029/2002JC001346, 2003.

Margalef, R.: Life-forms of phytoplankton as survival alternatives in an unstable environment, Oceanol. Acta, 1, 493-509, 1978.

Martinez, J. M., Schroeder, D. C., Larsen, A., Bratbak, G., and Wilson, W. H.: Molecular dynamics of Emiliania huxleyi and cooccurring viruses during two separate mesocosm studies, Appl. Environ. Microb., 73, 554-562, 2007.

McIntyre, A. and Bé, A. W. H.: Modern coccolithophoridae of the Atlantic Ocean. 1. Placoliths and cyrtoliths, Deep-Sea Res., 14, 561-597, 1967.

Mehrbach, C., Culberson, C. H., Hawley, J. E., and Pytkowitcz, R. M.: Measurements of the apparent dissociation constants of carbonic acid in seawater at atmospheric pressure, Limnol. Oceanogr., 18, 897-907, 1973.

Merico, A., Tyrrell, T., and Cokacar, T.: Is there any relationship between the phytoplankton seasonal dynamics and the carbonate system?, J. Marine Syst., 59, 120-142, 2006.

Mohan, R., Mergulhao, L. P., Guptha, M. V. S. Rajakumar, A., Thamban, M., Anilkumar, N., Sudhakar, M., and Ravindra, R.: Ecology of coccolithophores in the Indian sector of the Southern Ocean, Mar. Micropaleontol., 67, 30-45, 2008.

Molfino, B. and McIntyre, A.: Precession forcing of nutricline dynamics in the equatorial Atlantic, Science, 249, 766-769, 1990.

Nejstgaard, J. C., Gismervik, I., and Solberg, P. T.: Feeding and reproduction by Calanus fin- marchicus, and microzooplankton grazing during mesocosm blooms of diatoms and the coccolithophore Emiliania huxleyi, Mar. Ecol.-Prog. Ser., 147, 197217, 1997.

Nelson, D. M., Goering, J. J., Kilham, S. S., and Guillard, R. R. L.: Kinetics of silicic acid uptake and rates of silica dissolution in the marine diatom Thalassiosira pseudonana, J. Phycol., 12, 246-252, 1976.

Nishida, S.: Atlas of Pacific nannoplanktons, News Osaka, Micropaleonty, 3, 1-31, 1979.

Okada, H. and McIntyre, A.: Modern coccolithophores of the Pacific and North Atlantic Oceans, Micropaleontology, 23, 1-55, 1977. 
Okada, H. and McIntyre, A.: Seasonal distribution of modern coccolithophores in the western North Atlantic Ocean, Mar. Biol., 54, 319-328, 1979.

Okada, H. and Honjo, S.: The distribution of ocean coccolithophorids in the Pacific, Deep-Sea Res., 20, 335-374, 1973.

Oviedo, A. M., Langer, G., and Ziveri, P.: Effect of phosphorus limitation on coccolith morphology and element ratios in Mediterranean strains of the coccolithophore Emiliania huxleyi, J. Exp. Mar. Biol. Ecol., 459, 105-113, 2014.

Pinardi, N. and Masetti, E.: Variability of the large scale general circulation of the Mediterranean Sea from observations and modelling: a review, Palaeogeogr. Palaeoecl., 158, 153-173, 2000.

Probert, I. and Houdan, A.: The Laboratory culture of coccolithophores, in: Coccolithophores: From Molecular Processes to Global Impact, edited by: Thierstein, H. R. and Young, J. R., Springer, Germany, 217-250, 2004.

Psarra, S., Tselepides, A., and Ignatiades L.: Primary productivity in the oligotrophic Cretan Sea (NE Mediterranean): seasonal and interannual variability, Prog. Oceanogr., 46, 187-204, 2000.

Rabitti, S., Bianchi, F., Boldrin, A., Da Ros, L., Socal, G., and Totti, C.: Particulate matter and phytoplankton in the Ionian Sea, Oceanol. Acta, 17, 297-307, 1994.

Rahav, E., Herut, B., Levi, A., Mulholland, M. R., and BermanFrank, I.: Springtime contribution of dinitrogen fixation to primary production across the Mediterranean Sea, Ocean Sci., 9, 489-498, doi:10.5194/os-9-489-2013, 2013.

Ribera d'Alcalà, M., Civitarese, G., Conversano, F., and Lavezza, R.: Nutrient ratios and fluxes hint an overlooked processes in the Mediterranean sea, J. Geophys. Res., 108, 8106, doi:10.1029/2002JC001650, 2003.

Robinson, A. R., Leslie, W. G., Theocharis, A., and Lascaratos, A. : Mediterranean Sea circulation, in: Encyclopedia of ocean sciences, Academic Press, London, doi:10.1006/rwos.2001.0376, 2001.

Rohling, E. J., Abu-Zied, R., Casford, J. S. L., Hayes, A., and Hoogakker, B. A. A.: The marine environment: present and past, in: The Physical Geography of the Mediterranean, edited by: Woodward, J. C., Oxford University Press, Oxford, ISBN: 9780-19-926803-0, 33-67, 2009.

Sarthou, G., Timmermans, K. R., Blain, S., and Treguer, P.: Growth physiology and fate of diatoms in the ocean: a review, J. Sea Res., 53, 25-42, 2005.

Sverdrup, H. U.: On conditions for the vernal blooming of phytoplankton, ICES J. Mar. Sci., 18, 287-295, 1953.

Takahashi, K. and Okada, H.: Environmental control on the biogeography of modern coccolithophores in the southeastern Indian Ocean offshore of Western Australia, Mar. Micropaleontol., 39, 73-86, 2000.

Tanhua, T., Hainbucher, D., Cardin, V., Álvarez, M., Civitarese, G., McNichol, A. P., and Key, R. M.: Repeat hydrography in the Mediterranean Sea, data from the Meteor cruise 84/3 in 2011, Earth Syst. Sci. Data, 5, 289-294, doi:10.5194/essd-5-289-2013, 2013a.
Tanhua, T., Hainbucher, D., Schroeder, K., Cardin, V., Álvarez, M., and Civitarese, G.: The Mediterranean Sea system: a review and an introduction to the special issue, Ocean Sci., 9, 789-803, doi:10.5194/os-9-789-2013, 2013 b.

Triantaphyllou, M., Dimiza, M., Krasakopoulou, E., Malinverno, E., Lianou, V., and Souvermezoglou, E.: Seasonal variation in Emiliania huxleyi coccolith morphology and calcification in the Aegean Sea (Eastern Mediterranean), Geobios., 12th Meeting of the International Nannoplankton Association, Lyon 2008, 43, 99-110, 2010.

Tyrrell, T. and Young, J. R.: Coccolithophores, in: Encyclopedia of Ocean Sciences, 2nd Edn., edited by: Steele, J. H., Turekian, K. K., and Thorpe, S. A., Academic Press, San Diego, US, 35683576, 2009.

Tyrrell, T., Schneider, B., Charalampopoulou, A., and Riebesell, U. Coccolithophores and calcite saturation state in the Baltic and Black Seas, Biogeosciences, 5, 485-494, doi:10.5194/bg-5-4852008, 2008.

Vardi, A., Haramaty, L., Van Mooy, B. A., Fredricks, H. F., Kimmance, S. A., Larsen, A., and Bidle, K. D.: Host-virus dynamics and subcellular controls of cell fate in a natural coccolithophore population, P. Natl. Acad. Sci. USA, 109, 19327-19332, 2012.

Volpe, G., Colella, S., Forneris, V., Tronconi, C., and Santoleri, R.: The Mediterranean Ocean Colour Observing System - system development and product validation, Ocean Sci., 8, 869-883, 2012

Yacobi, Y., Zohary, T., Kress, N., Hecht, A., Robarts, R., Waiser, M., Wood, A., and Li, W.: Chlorophyll distribution throughout the southern Mediterranean in relation to the physical structure of the water mass, J. Mar. Syst., 6, 179-190, 1995.

Young, J. R.: Functions of coccoliths, in: Coccolithophores, edited by: Winter, A. and Siesser, W. G., Cambridge University Press, Cambridge, UK, 63-82, 1994.

Young, J., Geisen, M., Cros, L., Kleijne, A., Sprengel, C., Probert, I., and Østergaard, J.: A guide to extant coccolithophore taxonomy, J. Nannoplankton Res., 1, 1-125, 2003.

Ziveri, P., Thunell, R. C., and Rio, D.: Seasonal changes in coccolithophore densities in the Southern California Bight during 1991-1992, Deep-Sea Res. Pt. I, 42, 1881-1903, 1995.

Ziveri, P., Rutten, A., de Lange, G., Thomson, J., and Corselli, C.: Present-day coccolith fluxes recorded in central eastern Mediterranean sediment traps and surface sediments, Palaeogeogr. Palaeocl., 158, 175-195, 2000.

Ziveri, P., Baumann, K. H., Böckel, B., Bollman, J., and Young, J. R.: Present day coccolithophore biogeography in the Atlantic Ocean, in: Coccolithophores: From Molecular Processes to Global Impact, edited by: Thierstein, H. R. and Young, J. R., Springer Verlag, Berlin Heidelberg, 2004.

Ziveri, P., Thoms, S., Probert, I., Geisen, M., and Langer, G.: A universal carbonate ion effect on stable oxygen isotope ratios in unicellular planktonic calcifying organisms, Biogeosciences, 9, 1025-1032, doi:10.5194/bg-9-1025-2012, 2012. 